\title{
A Population of SCP-containing Neurons in the Buccal Ganglion of Aplysia Are Radula Mechanoafferents and Receive Excitation of Central Origin
}

\author{
Mark W. Miller, ${ }^{1,2,4}$ Steven C. Rosen, ${ }^{1}$ Scott L. Schissel, ${ }^{1}$ Elizabeth C. Cropper, ${ }^{2}$ Irving Kupfermann, ${ }^{1}$ and \\ Klaudiusz R. Weiss ${ }^{2,3}$ \\ ${ }^{1}$ Center for Neurobiology and Behavior, New York State Psychiatric Institute and College of Physicians and Surgeons of \\ Columbia University, New York, New York 10032, '2Department of Physiology and Biophysics and ${ }^{3}$ Fishberg Research \\ Center for Neurobiology, Mount Sinai School of Medicine, New York, New York 10029, and ${ }^{4}$ nstitute of Neurobiology, \\ University of Puerto Rico, San Juan, Puerto Rico 00901
}

The rostral cluster of SCP-immunoreactive cells, originally identified in each buccal hemiganglion of juvenile Aplysia, was examined in mature specimens. Immunohistochemical and dye-fill experiments showed that each rostral cluster consists of approximately $\mathbf{4 0}$ cells. Although these neurons exhibit heterogeneity of size and shape, all cells project an axon into the radula nerve. Tracing of dye-filled cells showed that they project to the layer of tissue that lines the inner surface of the food-grasping portion of the chitinous radula. This tissue contains SCP-immunoreactive nerve fibers and varicosities in regions corresponding to the projections of dye-filled neurons. Several observations indicate that rostral cluster neurons transduce tactile stimuli applied to the radula surface: (1) each cell responds to touch of a circumscribed receptive field with a rapidly adapting burst of action potentials, (2) the evoked spikes arise abruptly from the resting potential without prepotentials, and (3) the responses persist when central and peripheral synaptic transmission is blocked in high $\mathbf{M g}^{2+}$, low $\mathrm{Ca}^{2+}$ artificial seawater solutions. These cells, designated radula mechanoafferent (RM) neurons, do not respond to chemical stimuli including $\mathrm{NaCl}$, glutamate, and seaweed extract. The highest density of receptive fields is found on the posterodorsal edges of the radula halves, areas most directly involved in grasping food. The RM neurons are electrically coupled cells, with coupling coefficients ranging from 0.006 to 0.22 . They fire phasically during buccal motor programs, even in the absence of peripheral feedback from the radula or other portions of the buccal mass. In radiolabeling studies the RM cells were found to synthesize authentic $\mathbf{S C P}_{A}$ and $\mathbf{S C P}_{B}$. Sensorin-A, a peptide that is localized to other Aplysia mechanoafferent neurons, was not detected immunohistochemically in these cells.

\footnotetext{
Received Nov. 8, 1993; revised Apr. 11, 1994; accepted May 19, 1994.

We thank Bob Woolley for assistance with preparation of the figures and Elizabeth Lauenborg for help in preparation of the text. This study was supported by USPHS Grants MH51393, GM32099, MH35564, MH50235, and MH48190-02 (MIRDP), and funds from the Whitehall Foundation and the McKnight Endowment Fund for Neuroscience.

Correspondence should be addressed to Dr. K. R. Weiss, Mount Sinai School of Medicine, Department of Physiology and Biophysics, Box 1218, One Gustav L Levy Place, New York, NY 10029.

Copyright (C) 1994 Society for Neuroscience $0270-6474 / 94 / 147008-16 \$ 05.00 / 0$
}

[Key words: molluscan, feeding rhythm, mechanosensory, neuropeptides, neuromodulation, central pattern generator]

The stereotyped and repetitive behaviors associated with feeding in invertebrates provide favorable systems for examining the neural bases of behavior (Kater, 1974; Kupfermann, 1974b; Marder, 1988; Lent et al., 1989). Studies of feeding-related behaviors in gastropod mollusks have contributed to our understanding of the generation of motor patterning (Berry, 1972; Kater and Rowell, 1973; Benjamin and Rose, 1979; Susswein and Byrne, 1988), synaptic plasticity underlying modifications of behavior due to experience (Davis et al., 1974; Gelperin et al., 1985; Kovac et al., 1986; Kupfermann et al., 1989), and the role of neuromodulators in controlling complex behavior and central motive states (Kupfermann, 1974a; Davis et al., 1977; Susswein et al., 1978; Wciss et al., 1978; Trimble and Barker, 1984; Cropper et al., 1987a,b, 1988). In Aplysia, as in other animals, feeding-related behaviors can be classified into two major response categories-appetitive behaviors in which the animal locates and orients toward the food source, and consummatory behaviors during which ingestion occurs (Kupfermann, 1974a). Many neurons comprising the circuits underlying the more stereotyped consummatory behaviors have been identified. These include motor neurons that innervate the buccal muscles (Cohen et al., 1978; Kreiner et al., 1987; Church and Lloyd, 1991; Church et al., 1991), sensory neurons that exert specific actions upon the feeding circuitry (Rosen et al., 1979, 1982; Fredman and Jahan-Parwar, 1980; Weiss et al., 1986ac; Chiel et al., 1986), and premotor or interneurons that may participate in the initiation of rhythmic consummatory responses (Susswein and Byrne, 1988; Plummer and Kirk, 1990; Rosen et al., 1991).

The neuronal circuits controlling feeding are modulated by amines and neuropeptides that can originate from neurons within or extrinsic to the central pattern-generating network (Weiss et al., 1978; Kirk and Scheller, 1986; Cropper et al., 1987a,b, 1988; Ono, 1989; Church and Lloyd, 1991). Two such modulators, the small cardioactive peptides (SCPs; Lloyd, 1982, 1986), $\mathrm{SCP}_{\mathrm{B}}$ and $\mathrm{SCP}_{\mathrm{A}}$, were sequenced following purification from Aplysia tissues (Morris et al., 1982; Lloyd et al., 1987b). Exogenous application of the SCPs produces a number of actions at peripheral and central sites involved in feeding: they promote 
A

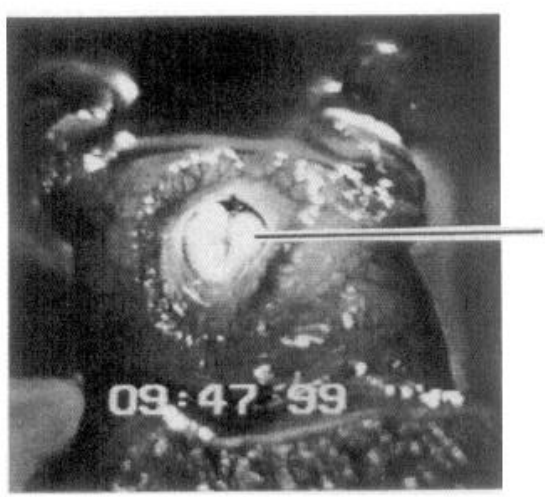

\section{B}

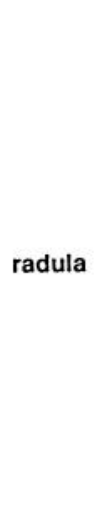

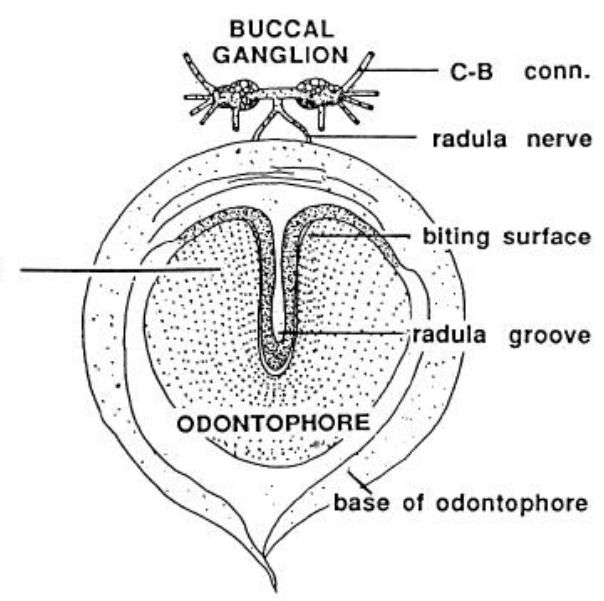

Figure 1. A, En face view of the head of Aplysia during a biting response. In this image the mouth is open and the odontophore is protracted and rotated forward. The radula, which caps the odontophore, is seen in its opened position. The biting response was evoked by a small piece of food (seaweed) that was applied to the lips. $B$, Drawing of the odontophore preparation used in the majority of experiments. Food is usually grasped by the posterodorsal edge (biting surface) of the radula, at the dorsal end of the radula groove. The dorsal surface of the chitinous radula with its rows of small teeth is seen atop the tissue forming the base of the odontophore, the tongue-like structure that rhythmically rotates forward and back during feeding. The innervation provided by the buccal ganglion, via the radula nerve, was preserved. Innervation provided by other buccal nerves was eliminated. $C-B$ conn, cerebralbuccal connective. gut motility (Lloyd et al., 1988), enhance evoked contractions of buccal muscles (Lloyd et al., 1984; Richmond et al., 1986; Cropper et al., 1987a), and produce excitatory responses in certain motor neurons (Sossin et al., 1987; Taussig et al., 1989), premotor neurons (Plummer and Kirk, 1990), and mechanosensory neurons (Rosen et al., 1989). The SCPs also have functional roles in the ganglia of numerous invertebrate species other than Aplysia (Lloyd, 1982; Evans and Calabrese, 1989; Homberg and Hildebrand, 1989; Zoran et al., 1989; Welsford and Prior, 1991; Watson and Willows, 1992).

Three distinct groups of neurons containing $\mathrm{SCP}_{\mathrm{B}}$-like immunoreactivity $\left(\mathrm{iSCP}_{\mathrm{B}}\right)$ were originally described in the buccal ganglia of very early postmetamorphic stage Aplysia (Lloyd et al., 1985). A prominent "esophageal group" of immunoreactive cells includes the large cells B1 and B2 (Gardner, 1971; see Kreiner et al., 1986; Reed et al., 1988). Cells in this group innervate the gut via the esophageal nerve (Lloyd et al., 1988). A second "ventral group" of immunoreactive buccal neurons consists of cells of varying staining intensity distributed throughout the ventral motor neuron cluster, several of which have been individually identified (Cropper et al., 1987a; Kreiner et al., 1987; Sossin et al., 1987; Church and Lloyd, 1991; Church et al., 1991). An additional cluster of $\mathrm{SCP}_{\mathrm{B}}$-immunoreactive cells, termed the "rostral group," consists of 15-25 densely packed neurons that appear to give rise to axons projecting toward the buccal commissure. Uniquely identifiable neurons have not been described in this cluster and the functional properties of these cells, including the role of the SCPs, have not been examined. In this study, we have used dye-filling and whole-mount immunocytochemical methods in conjunction with electrophysiological methods to analyze rostral group $\mathrm{SCP}_{\mathrm{B}}$-immunoreactive cells in mature Aplysia. These peptide-containing cells were found to be sensory neurons that respond to tactile stimuli applied to the radula, the structure that contacts food during biting. Furthermore, these cells exhibit spontaneous and evoked bursting patterns, even in the absence of peripheral stimuli, suggesting that they are strongly influenced by the central pattern generators (CPGs) that underlie buccal motor programs. The presence of modulatory peptides in mechanoafferents that are also driven by CPGs may enable such neurons to regulate pattern-generating networks via both central and peripheral actions. These results thus provide further evidence for the recently emerging view that there are complex bidirectional interactions between sensory neurons and central pattern-generating circuits that produce rhythmic stereotyped movements in both vertebrates and invertebrates (Dubuc et al., 1988; Libersat et al., 1989; reviewed in Cohen, 1992).

Some of the present results have been reported previously in abstract form (Miller et al., 1988).

\section{Materials and Methods}

Subjects and preparations. The experimental subjects were wild type Aplysia californica weighing 250-400 gm (Marinus, CA). They were maintained at $14-16^{\circ} \mathrm{C}$ in holding tanks containing aerated, filtered, artificial seawater (ASW). Isolated ganglia preparations and a dissected odontophore-buccal ganglion preparation were most often utilized, but experiments were also conducted with other types of reduced preparations (specified in Results). Animals were initially anesthetized by injection of isotonic $\mathrm{MgCl}_{2}$ ( $50 \%$ of body weight) and dissected. In isolated ganglia preparations, the buccal and cerebral ganglia were removed with the cerebral-buccal (C-B) connectives intact. In the odontophore-buccal ganglion preparation, the radula (shown in the intact feeding animal in Fig. $1 \mathrm{~A}$ ) and attached muscles and skin that form the odontophore were excised along with the buccal ganglion (Fig. 1B). A number of the larger muscles that lead into the odontophore were cut in order to free it from the floor of the buccal cavity. Particular care was taken to preserve the innervation provided by the radula nerve and in some cases buccal nerve 3 . The nomenclature for buccal neurons and nerves follows that of Gardner (1971). The odontophore was placed in a recording chamber so that it rested on its cut base and the toothed radula surface faced upward, similar to its resting position in the buccal mass.

Electrophysiology. Intracellular recordings were obtained from isolated ganglia or from reduced preparations maintained in a Lucite recording chamber that had a clear Sylgard silicon elastomer floor with a depth $(4-10 \mathrm{~mm})$ that was appropriate for the thickness of the different portions of the preparation. For intracellular recording and stimulation, neurons were impaled with double-barreled microelectrodes that were made of thin walled glass and contained $2 \mathrm{~m}$ potassium acetate. The electrodes were beveled so that their impedances ranged from 15-20 $\mathrm{M} \Omega$. For the purposes of identifying cells and examining their morphologies, the potassium acetate in the stimulating electrode was replaced by a $3 \%$ solution of 5(6)-carboxyfluorescein dye (Kodak) in 0.1 
M potassium citrate, titrated to $\mathrm{pH} 8.0$ with $\mathrm{KOH}$ (after Rao et al, 1986). These electrodes were beveled so that the impedance of the electrode containing the dye was $30-40 \mathrm{M} \Omega$ and the impedance of the potassium acetate electrode was 15-20 M $\Omega$. In other experiments, aimed at obtaining accurate measurements of the resting potentials of identified cells, the electrodes were filled with $2 \mathrm{M}$ potassium chloride and beveled so that their impedances were again between 10-15 M 2 . Up to four simultaneous intracellular recordings were obtained using conventional electrometers. A neuron from the B4 and B5 pair of multiaction (Gardner and Kandel, 1977), multifunction (Rosen et al, 1982; Jahan-Parwar et al., 1983) cells was often used as a reference for electrophysiological experiments (see Figs. 6, 7, 10, 11). Since these two neurons are difficult to distinguish, the more medial cell of the pair was always chosen for recording and is referred to as B4 in the text and figures (after Gardner and Kandel, 1977). Nerve recordings were made with polyethylene suction electrodes and AC (Grass P15) amplifiers.

Morphology. In order to visualize fine peripheral processes, neurons were filled with 5(6)-carboxyfluorescein dye by iontophoretic ejection from microelectrodes. To reduce the active transport of the dye out of the cells, probenecid (10 mM final concentration; Steinberg et al., 1987) was added to the ASW bathing medium and the preparation was kept for $24-48$ hr at $4^{\circ} \mathrm{C}$. The use of probenecid resulted in a dramatic improvement of the dye fills, particularly of small processes far from the cell body (see Rosen et al., 1991). The unfixed tissues were viewed with a fluorescence microscope (Leitz filter pack D). Confirmation of cell morphology was made with Lucifer yellow ejection (Stewart, 1978), followed by fixation in paraformaldehyde, and clearing in methyl salicylate.

Mechanical and chemical stimulation. The recording chamber was divided into two compartments that were interconnected by a Vaselinefilled notch, allowing selective application of mechanical or chemical stimuli to the odontophore. Tactile stimuli were provided by a fire polished Pasteur pipette or a set of flexible von Frey hairs consisting of polyethylene tubing that was heated and pulled to various diameters. The hairs were calibrated for delivery of punctate stimuli with forces ranging between 0.1 and $10 \mathrm{gm}$. Chemical stimuli consisted of a piece of moistened seaweed (Laver: dried Porphyra) presented by a hand-held forceps or graded concentrations of seaweed extract gently perfused over the radula (see Susswein et al., 1978). Other chemical stimuli consisted of $4 \mathrm{M} \mathrm{NaCl}$ and solutions of amino acids found in seaweed (e.g., glutamic acid; see Jahan-Parwar, 1972).

Immunocytochemistry. Previously described methods for indirect immunofluorescence whole-mount mapping of Aplysia ganglia were followed (see Longley and Longley, 1986; Miller et al., 1991). Individual neurons were identified by electrophysiological criteria and/or their responses to mechanosensory stimuli. Cells were filled with Lucifer yellow (4\%) by iontophoretic ejection (5-10 nA; pulses $0.5 \mathrm{sec}$ on, $0.5 \mathrm{sec}$ off; $30 \mathrm{~min}$ ) and ganglia were fixed for $2-4 \mathrm{hr}$ (room temperature) in $4 \%$ paraformaldehyde. Nonspecific antibody binding was blocked by preincubating tissues in a phosphate buffer solution containing $0.8-3 \%$ normal goat serum (NGS; Miles Sci., Naperville, IL) overnight at $4^{\circ} \mathrm{C}$. Primary rabbit antisera against (1) $\mathrm{SCP}_{\mathrm{B}}$ (provided by $\mathrm{A}$. Mahon; see Lloyd et al., 1985) and (2) a sequence (P1) of the sensorin-A precursor (provided by E. R. Kandel; see Brunet et al., 1991) were then applied (1:50 to 1:200 for $\mathrm{SCP}_{\mathrm{B}} ; 1: 200$ to $1: 500$ for $\left.\mathbf{P} 1\right)$. Following incubation and rinsing (1-2 d each), secondary antibody (goat anti-rabbit immunoglobulin $\mathrm{G}$, rhodamine-conjugated Fab fragment; Cappel, Malvern, $P A)$ was applied at a 1:50 or 1:100 dilution. Following incubation and washing, tissues were mounted on depression slides in phosphate buffer: glycerol (1:6), viewed under a Leitz microscope equipped with epifluorescence (filterpack N-2 for rhodamine, D for Lucifer yellow), and photographed.

Biochemistry. Forty-three physiologically identified rostral mechanoafferent neurons were marked by intracellular iontophoresis of fast green dye and radiolabeled as previously described (Cropper et al., $1987 \mathrm{a}$; Lloyd et al., 1987a,b). Briefly, buccal ganglia were incubated for $24 \mathrm{hr}$ in $1 \mathrm{ml}$ of $50 \%$ ASW, $50 \%$ hemolymph containing $0.5 \mathrm{mCi}$ of ${ }^{35} \mathrm{~S}$-methionine, $2.5 \mu \mathrm{l}$ of $1 \mathrm{M}$ colchicine (dissolved in DMSO), and 100 $\mu \mathrm{l}$ of antibiotics (penicillin and streptomycin, each at $50 \mathrm{U} / \mathrm{ml}$ ). Individual marked neurons were dissected and peptides were extracted by heating the cells for $10 \mathrm{~min}$ in $100 \mu$ of $0.1 \mathrm{M}$ TFA containing $5 \mathrm{nmol}$ of synthetic $\mathrm{SCP}_{\mathrm{A}}$ and $9 \mathrm{nmol}$ of synthetic $\mathrm{SCP}_{\mathrm{B}}$. Two sequential reversephase high-performance liquid chromatography (RP-HPLC) passes were used to compare chromatographic properties of $S C P_{A}$ and $S C P_{B}$ to those of radiolabeled peptides synthesized by the extracted cells. In both passes a $\mathrm{C}_{8}$ column was developed with a linear gradient that ran from $15 \%$ $\mathrm{CH}_{3} \mathrm{CN}$ (acetonitrile) to $45 \% \mathrm{CH}_{3} \mathrm{CN}$, in $30 \mathrm{~min}$. In the first RP-HPLC pass $0.01 \mathrm{M} \mathrm{CF}_{3} \mathrm{COOH}$ (trifluoroacetic acid, TFA) was included in all solvents. The second pass was performed in the presence of $0.01 \mathrm{M}$ $\mathrm{F}_{7} \mathrm{BtOH}$ (heptafluorobutyric acid, $\mathrm{HFBA}$ ). The elution times of radiolabeled peptides were determined by scintillation counting of $10 \%$ of fraction aliquots. Synthetic peptides were detected by absorbance measurements at $215 \mathrm{~nm}$.

\section{Results}

\section{Morphological characteristics of the rostral cluster neurons}

In mature specimens of Aplysia, a cluster of closely apposed $\mathrm{SCP}_{\mathrm{B}}$-immunoreactive cells is located on the rostral surface of each buccal hemiganglion (Fig. $2 A$, arrows; see also Church et al., 1991). In living preparations, these cells have a pale, flat appearance, and lie in the central region of the hemiganglion, between the large ventral motor neurons and the small pigmented cells comprising the rostral portion of the $s_{2}$ cluster (Fiore and Muenier, 1979). This cluster of iSCP $\mathrm{B}_{\mathrm{B}}$ cells is likcly to correspond to the "rostral group" of buccal neurons described previously in very small ganglia obtained from juvenile animals (Lloyd et al., 1985). The rostral group of iSCP $_{B}$ neurons in juveniles consists of 15-25 tightly grouped neurons that are spatially graded in size (larger cells occupying more medial positions) and project axons toward the buccal commissure and the radula nerve (Lloyd et al., 1985). The rostral group neurons in mature specimens share several of these properties (compare Fig. $2 A, B$ ). They project axons toward the buccal commissure (Fig. 2C, arrows) and exhibit a spatial gradient of size (see below).

The total number of iSCP $_{\mathrm{B}}$ cells in each rostral cluster in adults ranged from 30 to 55 (numerical composition summarized in Table 1). The larger number of cells seen in the mature animals may reflect a developmental increase (see Cash and Carew, 1989) or may be due to an enhanced ability to resolve these neurons in the larger ganglia. Although substantial differences in the composition of the rostral clusters of the two hemiganglia were sometimes observed in individual preparations, the overall findings were not indicative of asymmetry.

The $\mathrm{SCP}_{\mathrm{B}}$-immunoreactive rostral cluster neurons of mature specimens exhibit considerable heterogeneity of size and form. One to four distinctively larger cells with elongated or ovoid shapes (80-120 $\mu \mathrm{m}$ in length) were typically present in the portion of the cluster closer to the commissure, and smaller spherical cells $(20-50 \mu \mathrm{m}$ in diameter) were located more laterally (Fig. 2D,E; Table 1). Dye fills of the ovoid cells revealed a bipolar form (see, for example, Fig. $3 C$ ). The spherical cells were generally found to be monopolar, with axons projecting toward the radula nerve, but further details of their branching patterns and forms were variable and were not systematically examined.

Electrophysiological and dye-filling experiments showed that the large and small neurons of the rostral group project axons into the buccal commissure and exit the ganglion via the radula nerve (Fig. 3). Extracellular radula nerve recordings (Fig. $3 \mathrm{~A}$, $\mathrm{rad}$.) revealed action potentials that corresponded $1: 1$ with impulses produced by injection of depolarizing current into the somata of rostral cluster cells (Fig. $3 A$, cells 1 and 2, arrows). Furthermore, action potentials could be recorded from these neurons in response to electrical stimulation of the radula nerve (Fig. 3B). These impulses arose from a stable baseline, with no indication of synaptic prepotentials. They were diminished in a stepwise manner, by passing hyperpolarizing current into the 

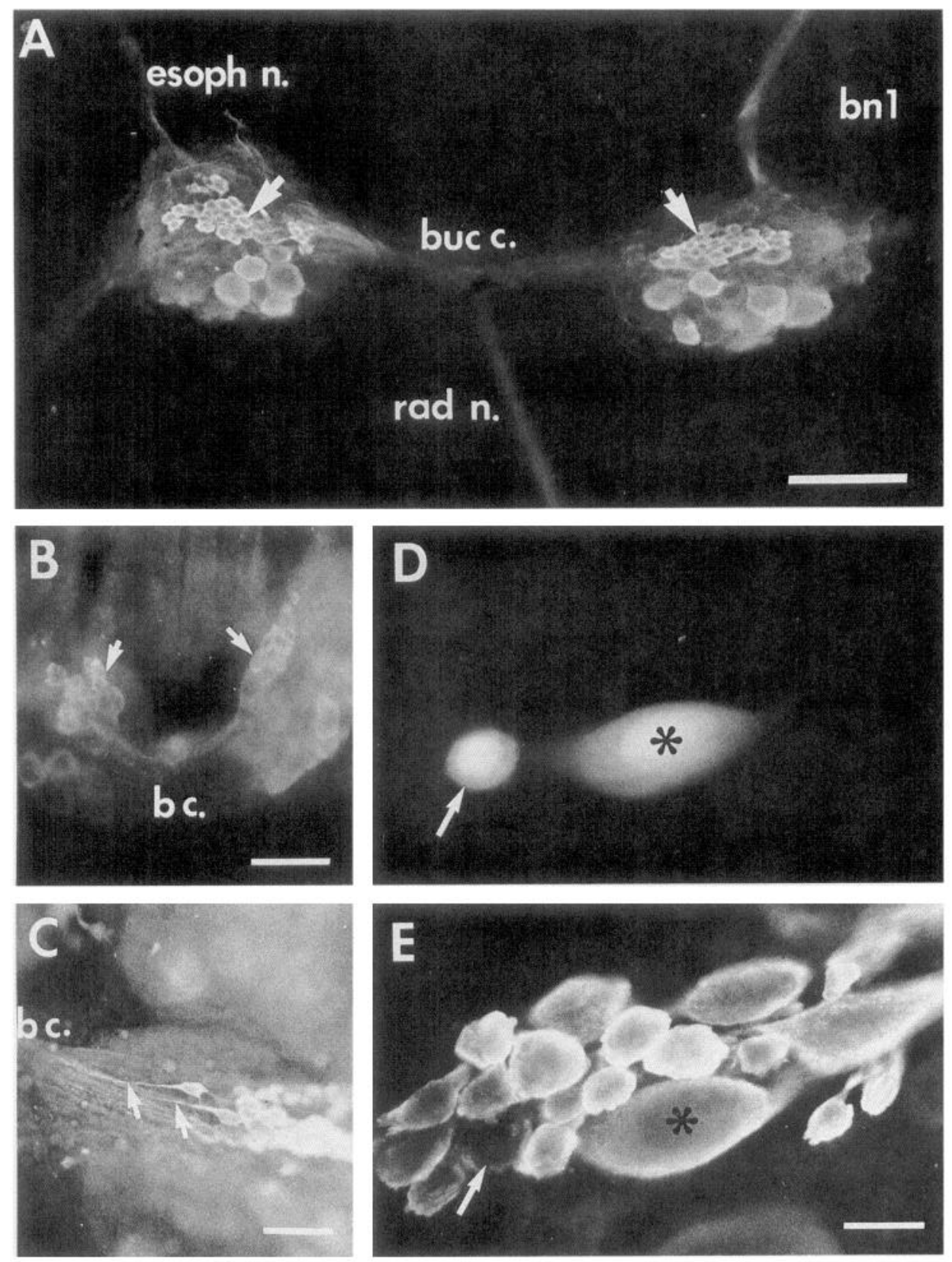

Figure 2. The rostral cluster of SCPimmunoreactive cells. $A$, Whole-mount of SCP-immunoreactivity in the left and right buccal hemiganglia of a mature (400 gm) specimen. The largest cells containing immunoreactive material belong to the ventral cluster of motor neurons (see Lloyd et al., 1985; Church et al., 1991). The rostral clusters (arrows) are composed of smaller closely apposed cells in the central region of each hemiganglion. esoph n., esophageal nerve; buc c., buccal commissure; rad $n$., radula nerve; $b n I$, buccal nerve 1. $B, \mathrm{SCP}_{\mathrm{B}}$-like immunoreactivity in the buccal ganglia of a juvenile (1.0 gm) animal. Rostral clusters indicated by arrows. The cells of these clusters appear to project axons toward the buccal commissure $(b c$. ). $C$, Rostral cluster of SCP-immunoreactive cells in adult specimen. Plane of focus is on the processes of these cells (arrows) directed toward the buccal commissure $(b c$. $)$. $D$, Two rostral cluster neurons (arrow and asterisk) filled with Lucifer yellow dye by ejection from an intracellular microelectrode. Note higher concentration of dye in the cell nuclei. $E$, The same field as $D$, following processing for $\mathrm{SCP}_{\mathrm{B}}$-like immunoreactivity (rhodamine-coupled second antibody). The immunoreactive material is present in the cytoplasmic region of the rostral cluster neurons, including the two filled cells shown in $D$ (arrow and asterisk). Note differences in cell shape (see Results). Scale bars: $A, 400 \mu \mathrm{m} ; B, 200$ $\mu \mathrm{m} ; C, 100 \mu \mathrm{m} ; D$ and $E, 50 \mu \mathrm{m}$. cell body (Fig. $3 B$ ). This reduction is likely to result from block of the approaching action potential at progressively more distal sites. Lucifer yellow dye fills of rostral cluster neurons confirmed that they project axons into the radula nerve (Fig. $3 C$ ). The larger ovoid cells, for example, the one illustrated, branched at the initial bifurcation of the radula nerve, extending fibers bilaterally (Fig. $3 C$, curved arrow).

In order to visualize the distal projections of neurons in the region of the rostral cluster, cells were filled with 5(6)-carboxyfluorescein dye (see Materials and Methods). Axons originating from cells in each hemiganglion could be traced into the radula nerve (Fig. $4 A$, rad n.). These axons bifurcated at the initial division of the radula nerve, extending a single fiber into each branch (Fig. $4 B$, arrow). The axons then coursed rostrally through the odontophore and did not further subdivide until reaching a layer of tissue underlying the surface of the chitinous radula (Fig. $4 C$ ). This subradula tissue is a site of insertion of certain
Table 1. Numerical composition of left and right rostral clusters of $\mathrm{SCP}_{\mathbf{B}}$-immunoreactive neurons in the buccal ganglia of Aplysia $^{a}$

\begin{tabular}{lrcc} 
Cell type & Mean & SD & Range \\
\hline Left hemiganglion & & & \\
Total & 40.27 & 7.04 & $30-53$ \\
$\quad$ Ovoid & 2.73 & 0.80 & $1-4$ \\
$\quad$ Spherical & 38.27 & 6.37 & $30-49$ \\
Right hemiganglion & & & \\
Total & 41.60 & 6.08 & $32-55$ \\
Ovoid & 2.60 & 0.91 & $1-4$ \\
Spherical & 39.27 & 5.55 & $31-53$ \\
\hline
\end{tabular}

${ }^{a}$ Based on cell counts from 15 specimens (30 hemiganglia). 

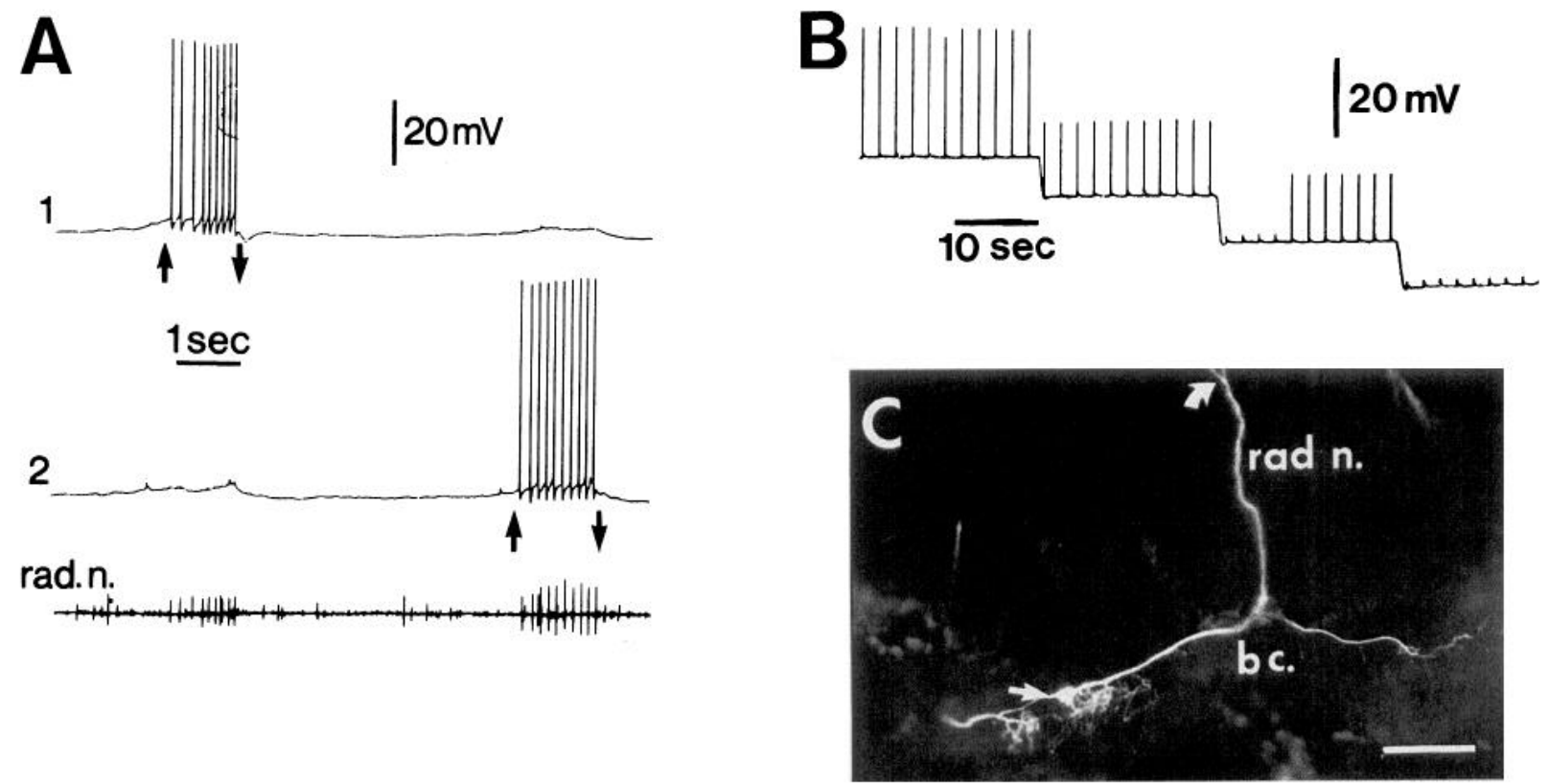

Figure 3. Neurons of the rostral cluster project axons into the radula nerve. $A$, Two neurons ( 1 and 2$)$ in the rostral cluster were caused to fire by passing depolarizing intrasomatic current (between upward and downward arrows). Action potentials corresponding 1:1 with the impulses of each cell were recorded extracellularly from the primary contralateral branch of the radula nerve ( $\mathrm{rad} n$.). $B$, Intracellular recording from the cell body of a rostral cluster neuron. Impulses were produced by extracellular stimulation $(0.5 \mathrm{~Hz})$ of the primary contralateral nerve branch of the radula nerve. In contrast to the impulses produced by intrasomatic current injection (see $A$ ), these action potentials did not overshoot the bath potential or undershoot rest potential. They were diminished in a stepwise manner, by hyperpolarizing the cell body in a series of $10 \mathrm{mV}$ steps. Small deflections at final two levels are stimulus artifacts. $C$, Large ovoid neuron in the medial part of the rostral cluster of the left buccal hemiganglion filled with Lucifer yellow (straight arrow). Two major processes arise from the poles of the cell body and numerous secondary and tertiary branches can be seen extending into the region of the ventral motor neuron cluster. One major process extends into the buccal commissure $(b c$.) where it branches, extending one fiber into the contralateral hemiganglion and one into the radula nerve ( $\mathrm{rad} \mathrm{n}$.). The fiber in the radula nerve branches at the initial bifurcation of the nerve (curved arrow). Scale bar, $550 \mu \mathrm{m}$.

intrinsic muscles of the buccal mass (Rosen et al., unpublished observations). The filled axons projected to specific regions of the subradula tissue, where they ramified extensively and appeared to terminate (Fig. $4 D$ ). Swellings or varicosities could be seen along the course of the terminal branches (Fig. $4 D$, arrows).

The localization of $\mathrm{SCP}_{\mathrm{B}}$-like immunoreactive material in the subradula tissue was determined using immunocytochemical techniques. A bundle of 15-20 immunoreactive fibers was found to enter the posterior portion of the subradula tissue where it subdivided, sending smaller groups of fibers to various portions of the tissue (Fig. 5A, arrow). Fine fibers connecting intensely stained punctate varicosities were present in regions corresponding to the terminal fields of filled rostral cluster neurons (Fig. $5 B$, arrows). Although it was not possible to conduct direct double-labeling experiments [due to the loss of 5(6)-carboxyfluorescein in fixed preparations] this localization of $\mathrm{SCP}_{\mathrm{B}}$-like immunoreactivity in the subradula tissue is consistent with the conclusion that this structure is innervated by neurons of the rostral cluster.

\section{Sensory responses of rostral cluster neurons}

The peripheral projections of rostral cluster neurons to the subradula tissue suggested that these cells might serve motor or sensory functions. Although sheets of muscle are present within the subradula tissue, and this structure has been observed to exhibit contractile properties (F. S. Vilim, personal communication), no movements were observed in response to stimulation of cells in this region of the ganglion ( $n=14$; six preparations). Several modalities of behaviorally relevant sensory stimuli were then applied to the radula surface while recording intracellular responses from multiple neurons in the region of the rostral cluster (Fig. 6, RM-1, RM-2, and RM-3). Responses were compared to those produced in the readily identified, multiaction, multifunction neuron B4 (Gardner and Kandel, 1977; Rosen et al., 1982; Jahan-Parwar et al., 1983). Mechanical stimuli were found to evoke robust, short-latency responses in the majority of the cells tested, as well as in neuron B4 (Fig. 6 $6 A_{1}$ ), whereas chemical stimuli consisting of seaweed (Fig. $6 A_{2}$ ), solutions of seaweed extract, amino acids, or high concentrations of salt (4 м NaCl; Fig. $6 A_{3}$ ) failed to evoke responses in any of the cells tested.

Several observations indicate that the neurons of the rostral cluster are primary mechanoafferents. In the majority of observed instances, evoked spikes did not exhibit prepotentials (e.g., Fig. $6 B_{t}$ ). In contrast, the impulses evoked in neuron B4 were always preceded by relatively large graded synaptic potentials. In cases where prepotentials were observed in the rostral cluster neurons, these were likely to be the result of electrical coupling to other RM neurons that have overlapping receptive fields and were stimulated simultaneously (see following sections). The role of rostral cluster cells as primary mechanoafferents is also supported by the observation that responses to tactile stimuli persisted after the odontophore and the buccal ganglion were bathed for several hours in an ASW solution containing a high concentration of $\mathrm{Mg}^{2+}(4 \times$ normal content $)$ and a low concentration of $\mathrm{Ca}^{2+}(0.5 \times$ normal content), a solution that effectively blocks chemical synaptic transmission (Fig. $6 B_{2}$; see Rosen et al., 1982). The depolarizing responses 

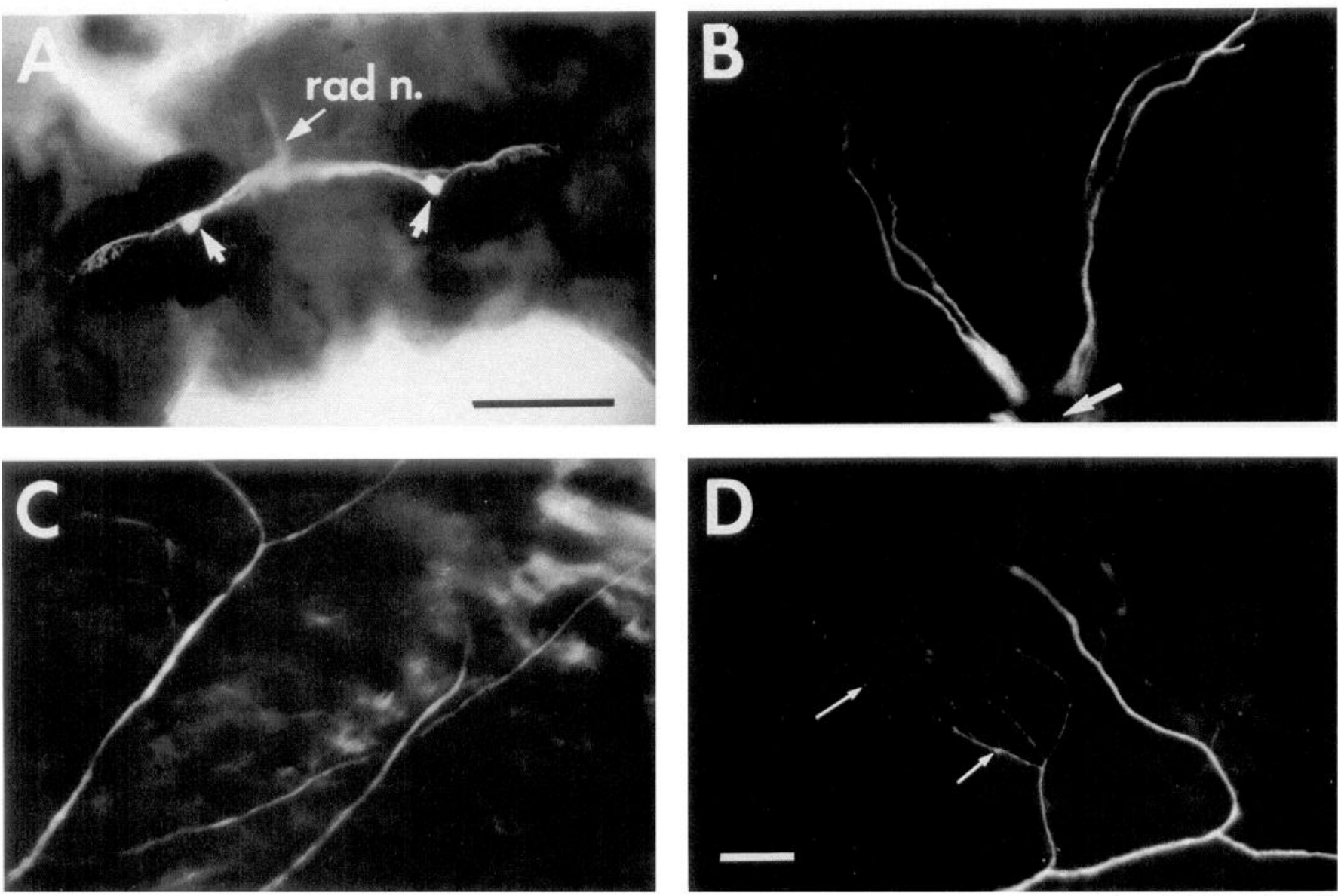

Figure 4. Bilateral pair of large, medial rostral cluster neurons filled with 5(6)-carboxyfluorescein dye. A, Low-power view of the buccal ganglion showing the somata and central processes of the two filled cells. An axon from each cell projects into the radula nerve ( $\mathrm{rad} n$.). $B$, Dye-filled fibers distal to the initial bifurcation of the radula nerve (arrow). Each main branch of the radula nerve contains two axons, one from the filled cell in the left hemiganglion and one from the filled cell in the right hemiganglion. $C$, Branching of these axons in the membrane that underlies the chitinous radula. $D$, Axons of rostral cluster neurons terminate in multiple fire neurites. With higher magnification, swellings or varicosities (arrows) that vary in size and shape can be seen along the course of the terminal branches. Scale bars: $A, 2 \mathrm{~mm} ; B-D$ (bar shown in $D$ ), $1 \mathrm{~mm}, 50 \mu \mathrm{m}$, and $20 \mu \mathrm{m}$, respectively.
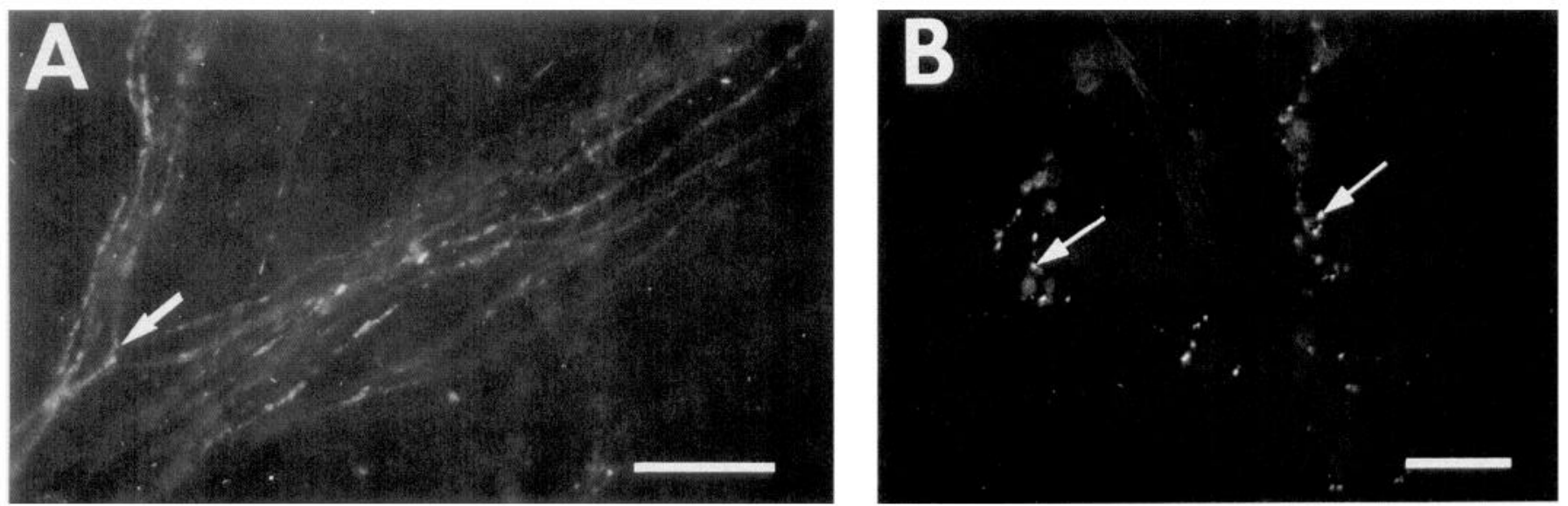

Figure 5. $\mathrm{SCP}_{\mathrm{B}}$-like immunoreactivity in the subradula tissue. $A$, A group of $15-20$ fibers containing immunoreactive material enters the posterior region of the subradula tissue. In this image, a secondary bundle branches off from the major group (arrow). En passant varicosities or swellings appear along the lengths of most fibers. $B$. High-power view of immunoreactive enlargements (arrows) present along fine fibers in a region of the subradula tissue that corresponds to the terminal fields of the rostral cluster cells (see Fig. 4). Scale bars: $A, 100 \mu \mathrm{m} ; B, 20 \mu \mathrm{m}$. 
Figure 6. Sensory responses of $\mathrm{iSCP}_{\mathrm{B}}$ rostral cluster neurons. $A_{l}$, Responses of three rostral cluster cells to a punctate tactile stimulus ( $2 \mathrm{gm}$ von Frey hair) applied (at arrow) to the biting surface of the radula. The traces represent simultaneous intracellular recordings from a large bipolar $(R M-1)$, an intermediate-sized $(R M-2)$, and a small monopolar $(R M-3)$ rostral cluster neuron. A control recording was also made of the responses of identified (ipsilateral) multifunction neuron $B 4$ that rcceives convergent sensory inputs from a variety of sources (Rosen et al., 1982, 1991; Jahan-Parwar et al., 1983). $A_{2}$, Recordings from the same cells as in $A_{t}$ during application of seaweed $\left(1 \mathrm{~cm}^{2}\right.$ moistened piece of Laver) to the biting surface of the radula for the period denoted by the horizontal event line. No responses were observed. $A_{3}$, Absence of responses of the cells in $A_{t}$ to superfusion of $4 \mathrm{M} \mathrm{NaCl}(100 \mu \mathrm{l})$ over the biting surface of the radula for the period denoted by the event line. $A_{4}$, Control responses of the RM neurons to the tactile stimulus in $A_{I}$ that were recorded following the tests of chemosensitivity in $A_{2}$ and $A_{3} . B_{1}$, Control responses of three SCP-immunoreactive cells $(R M$ $1, R M-2$, and $R M-3$ ) and neuron $\mathrm{B} 4$ to a tactile stimulus ( $2 \mathrm{gm}$ von Frey hair) applied (at arrow) to the biting surface of the radula. $B_{2}$, Persistence of the RM neuron responses to the tactile stimulus after the odontophore and buccal ganglion were bathed for $2 \mathrm{hr}$ in an ASW solution that contained high $\mathbf{M g}^{2+}(4 \times$ normal content) and low $\mathrm{Ca}^{2+}(0.5 \times$ normal content) concentrations. Reduction of the amplitude of the RM cell impulse could reflect a $\mathrm{Ca}^{2+}$ contribution to its soma or axon action potential (Geduldig and Junge, 1968; Horn, 1978). This solution blocks both peripheral and central chemical synapses. Note that the action potential responses of $B 4$ were abolished. The remaining B4 potentials are the result of electrical coupling between some of the RM neurons that are activated by the stimulus and neuron B4 (S. C. Rosen, unpublished observations). $B_{3}$, Control responses recorded $30 \mathrm{~min}$ after the high $\mathrm{Mg}^{2+}$, low $\mathrm{Ca}^{2+}$ solution was replaced with normal ASW.
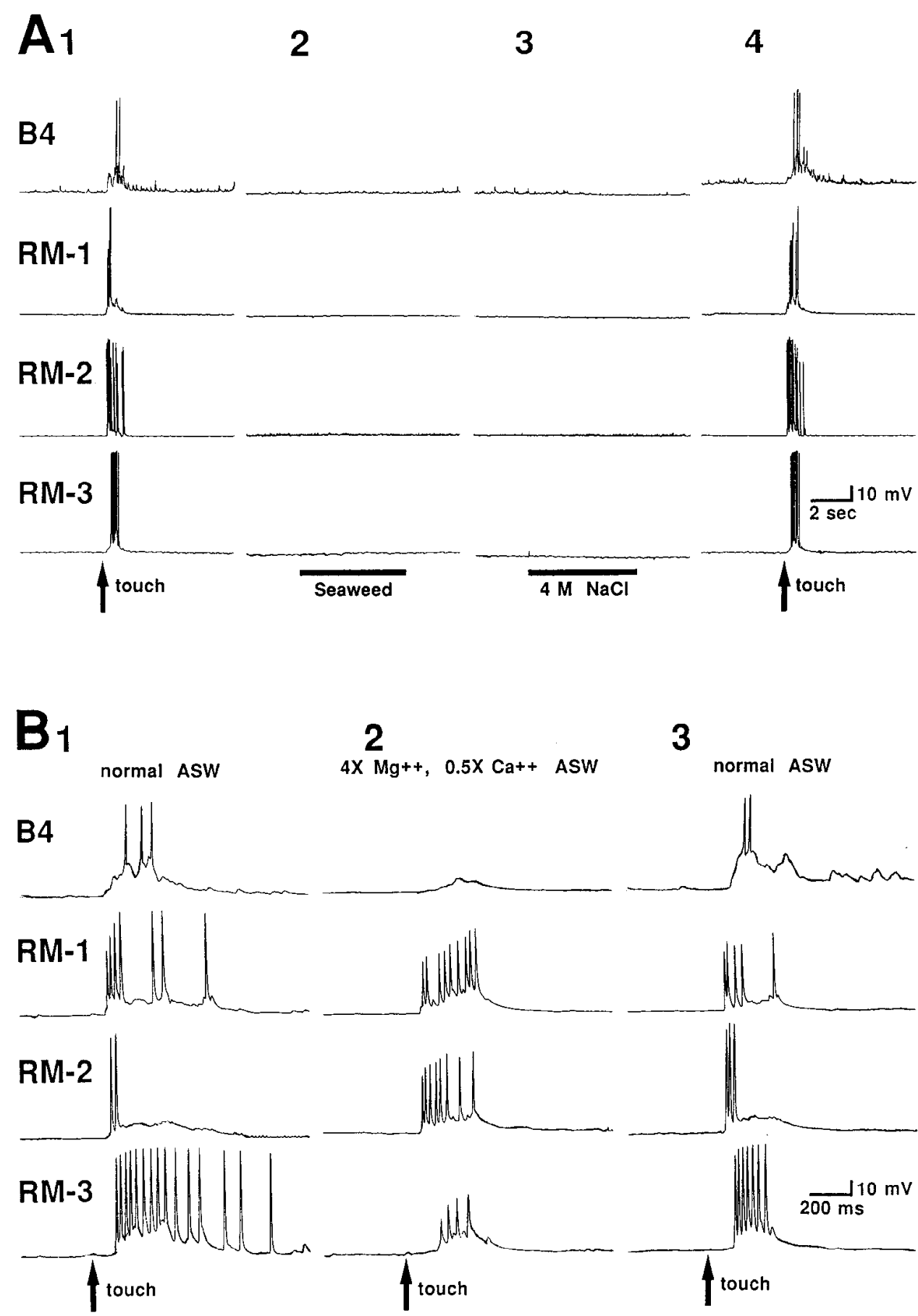

of neuron $\mathrm{B} 4$ were substantially diminished in the high $\mathrm{Mg}^{2+}$, low $\mathrm{Ca}^{2+}$ solution (Fig. $6 B_{2}$ ), and were restored when the preparation was returned to normal ASW (Fig. $6 B_{3}$ ).

These observations indicate that cells in the rostral cluster are primary mechanoafferents that innervate the subradula tissue. These cells have therefore been designated radula mechanoafferents (RMs). These experiments leave unresolved, however, two questions regarding the exact relationship between the histologically defined (i.e., $\mathrm{SCP}_{\mathrm{B}}$-immunoreactive) rostral cluster neurons and the functionally-defined radula mechanoafferents. Are all radula mechanoafferent neurons $\mathrm{SCP}_{\mathrm{B}}$ immunoreactive? Moreover, are all iSCP $\mathrm{B}_{\mathrm{B}}$ rostral cluster neurons radula mechanoafferents? In order to answer these questions, neurons in the region of the rostral cluster ( 51 neurons in nine preparations) were identified as radula mechanoafferents, marked with dye, and subsequently processed for $\mathrm{SCP}_{\mathrm{B}}$-like immunoreactivity (summarized in Table 2). In such experiments, 26 of 26 ovoid cells tested exhibited both mechanoafferent properties and $\mathrm{SCP}_{\mathrm{B}^{-}}$ like immunoreactivity. On the other hand, of 25 small spherical mechanosensory cells tested, only 14 contained immunoreactive material. It appears, thereforc, that the iSCP $_{\mathrm{B}}$ rostral cluster represents a subset of the total population of radula mechanoafferent cells in this region of the ganglion. In the course of these experiments, six small neurons in the region of the rostral cluster that did not exhibit mechanosensory responses were filled and processed for $\mathrm{SCP}_{\mathrm{B}}$-like immunoreactivity. Only one of 
$\mathbf{A}_{1}$

2

\section{3}

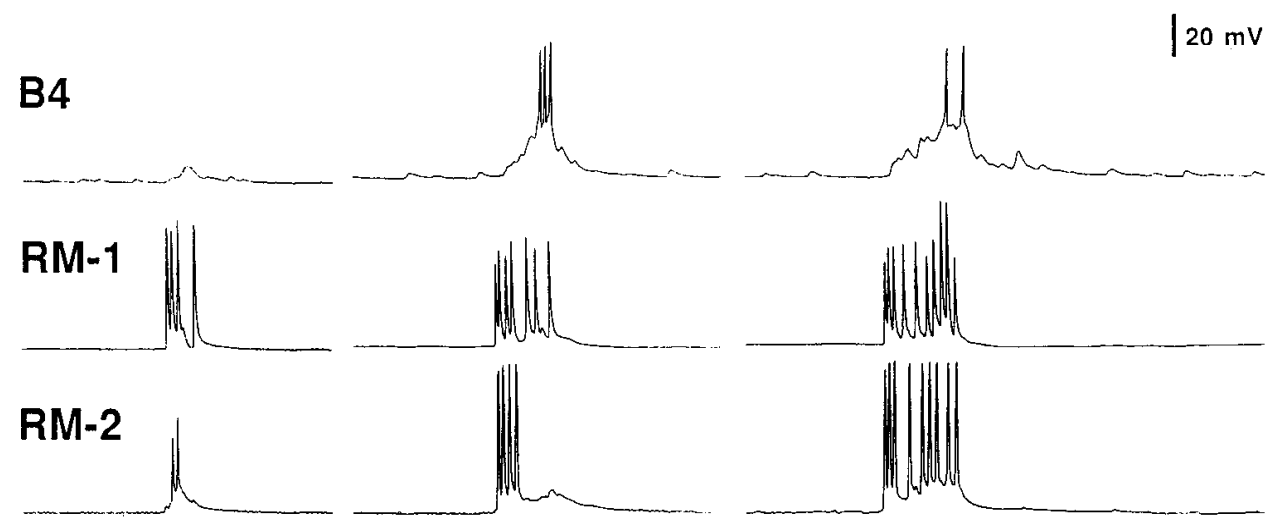

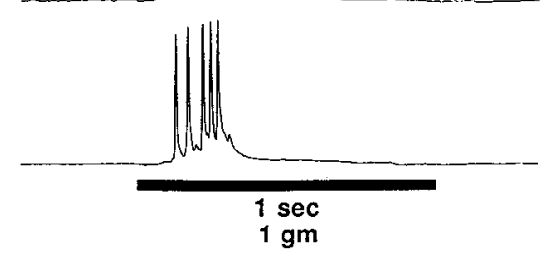

$\mathrm{B}_{1}$

B4
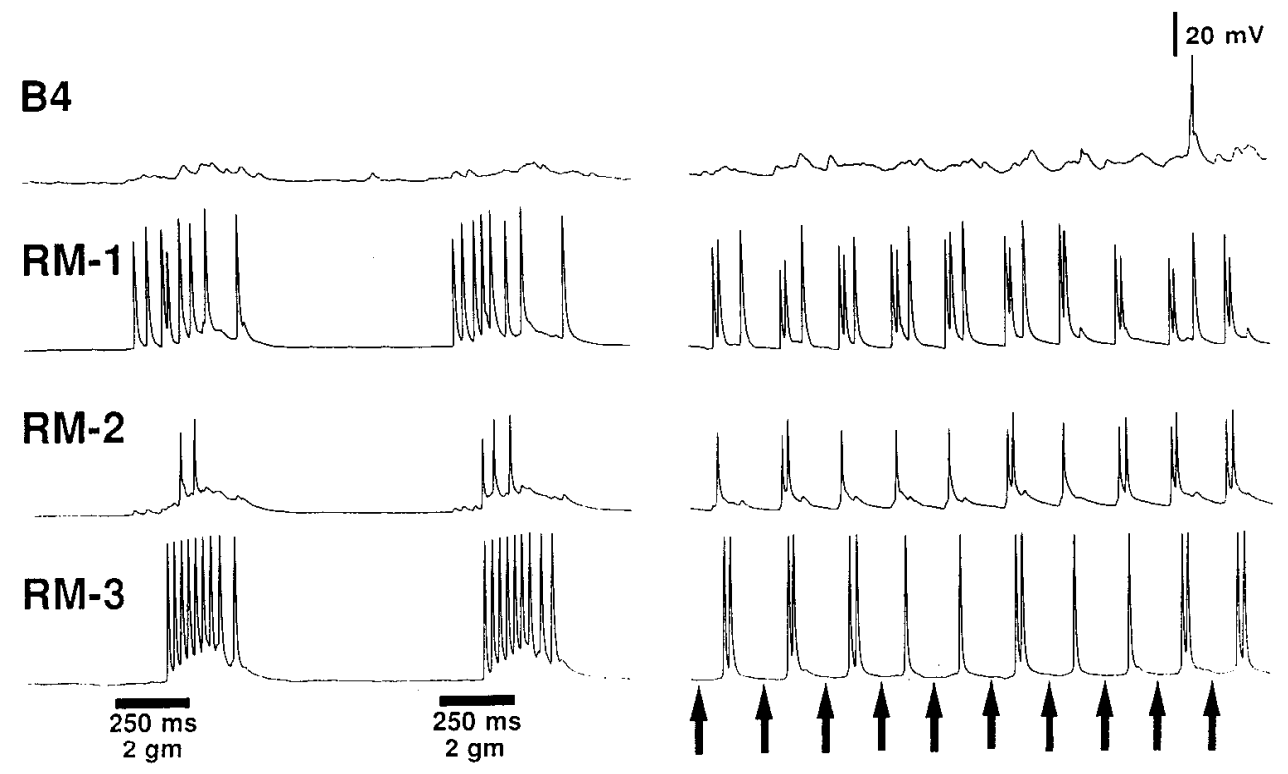

Figure 7. A, Responses of a large $(R M$ $1)$, medium ( $R M-2)$, and small $(R M-3)$ radula mechanoafferent neuron to a 1 gm von Frey hair applied to the radula for progressively increasing durations $\left(A_{1}-A_{3}\right.$, Stimuli indicated by horizontal bars). Control responses were recorded from an identified $B 4$ neuron in the same buccal hemiganglion. The RM neurons had overlapping receptive fields and the stimulus was applied to a locus common to all the fields. Note that the responses to the $1 \mathrm{sec}$ tactile stimulus all showed rapid adaptation. $B$, The ability of RM neurons to recover from adaptation is shown when a pair of $250 \mathrm{msec}$, $2 \mathrm{gm}$ tactile stimuli were applied 750 msec apart $\left(B_{t}\right)$. The responses to the second stimulus were equivalent to those of the first. The recovery function is also evident by the ability of the cells to respond to a $2 \mathrm{gm}, 100 \mathrm{msec}$ stimulus repcatcdly applied at $6 \mathrm{~Hz}\left(B_{2}\right)$. these neurons was iSCP ${ }_{\mathrm{B}}$ positive, and the dye fill suggested that the axon of this cell may have been damaged, thereby precluding the possibility of identifying it as a mechanoafferent. It remains possible, therefore, that all iSCP $\mathrm{B}_{\mathrm{B}}$ neurons of the rostral cluster are radula mechanoafferents.

\section{Response properties and receptive fields of radula mechanoafferent neurons}

The RM cells appear to be tuned to respond to punctate tactile stimuli applied to the biting surface of the radula. A brief (e.g., $100 \mathrm{msec})$ application of a calibrated von Frey hair ( $\sim \mathrm{gm})$
Table 2. Number of ovoid or spherical mechanoafferents showing $\mathrm{SCP}_{\mathrm{B}}$-like immunoreactivity ${ }^{\mathrm{a}}$

\begin{tabular}{lccccc}
\multirow{2}{*}{$\begin{array}{l}\text { Hemi- } \\
\text { ganglion }\end{array}$} & Ovoid & & \multicolumn{2}{c}{ Spherical } \\
\cline { 2 - 3 } \cline { 5 - 6 } \cline { 5 - 6 } & RM & iSCP & & RM & iSCP \\
\hline Left & 17 & 17 & & 11 & 8 \\
Right & 9 & 9 & 14 & 6 \\
$\quad$ Total & 26 & 26 & 25 & 14
\end{tabular}

a Neurons in the region of the rostral cluster were identified as radula mechanoafferent (RM) cells, filled with Lucifer yellow dye, and processed for $\mathrm{SCP}_{\mathrm{B}}$-like immunoreactivity $\left(\mathrm{iSCP}_{\mathrm{B}}\right)$. 


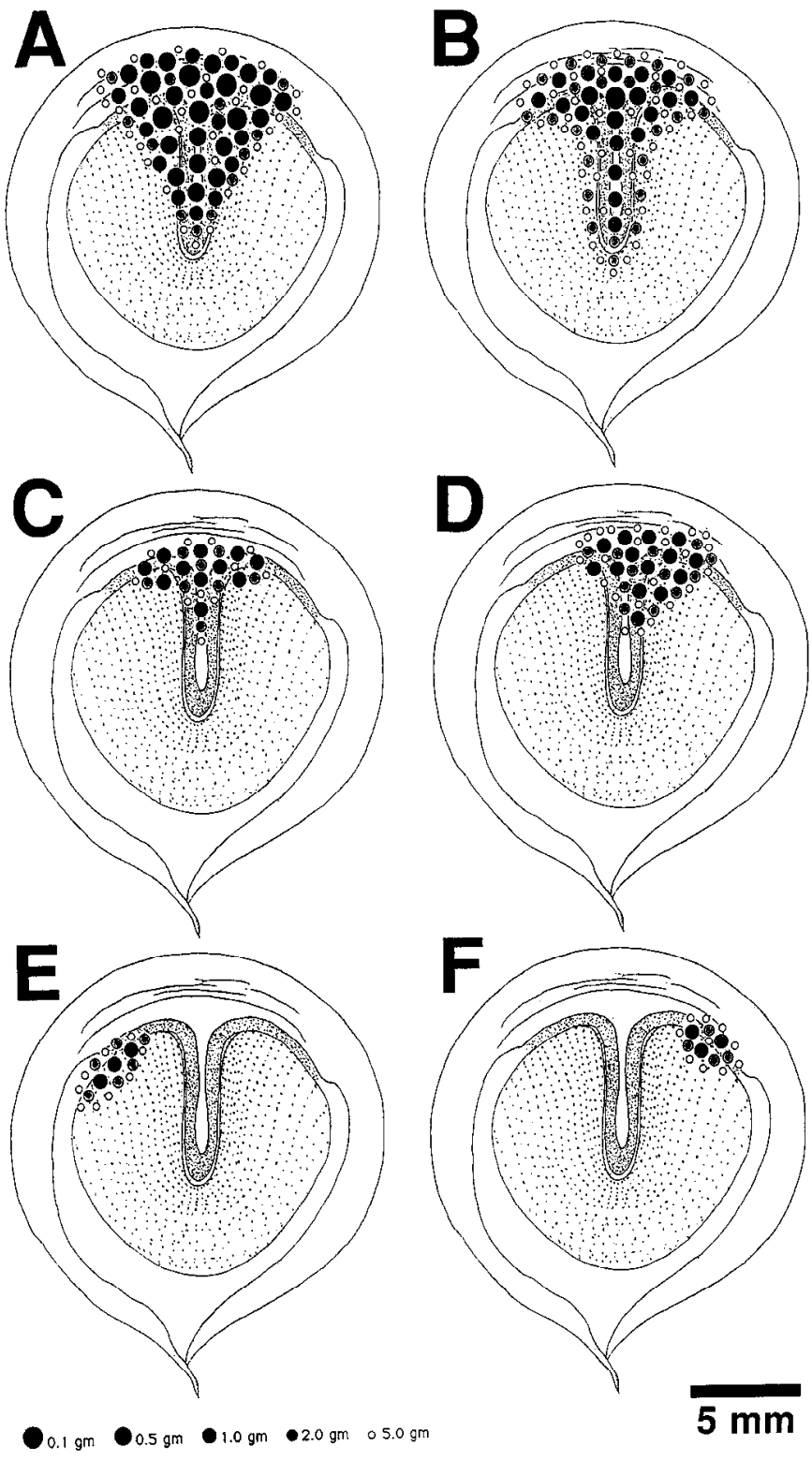

Figure 8. Receptive field locations and sensory threshold measurements of six representative radula mechanoafferent neurons found in the right buccal hemiganglion of a single preparation. $A$ and $B$, Receptive fields of two large bipolar RM neurons in the medial region of the rostral cluster. These cells had large, bilateral receptive fields and low thresholds; that is, they responded $>50 \%$ of the time to a $0.1 \mathrm{gm}$ von Frey hair (see legend). $C$ and $D$, Receptive fields of two medium-sized RM neurons. These cells also had bilateral receptive fields, but these were smaller in total area (compare with $A, B$ ). The thresholds for the medium sized RM cells were generally $\geq 0.5$ gm. $E$ and $F$, Receptive fields of two small RM neurons. The small RM neurons typically had small, unilateral receptive fields and relatively high sensory thresholds $(\geq 1.0$ gm).

generally elicited a burst of spikes (Fig. $7 A_{l}$ ). Stimulus application of longer duration (to $250 \mathrm{msec}$ ) resulted in higher frequency, longer duration spike bursts (Fig. $7 A_{2}$ ). However, when stimuli lasting more than $1 \mathrm{sec}$ were applied, all cells showed adaptation (Fig. $7 A_{3}$ ). No cell showed an off response when a stimulus was withdrawn from the radula. The adaptation of most of the RM cells was short lived. Robust responses to a $250 \mathrm{msec}, 2 \mathrm{gm}$ stimulus could be repeatedly evoked without decrement when the interstimulus interval was $750 \mathrm{msec}$ (Fig. $\left.7 B_{I}\right)$. The RM cells could be repeatedly activated by briefer ( 50 $\mathrm{msec}$ ) stimuli delivered at a rate of up to $6 \mathrm{~Hz}$ (Fig. $7 B_{2}$ ).

Like most other populations of mechanoafferent neurons described in Aplysia (Byrne et al., 1974; Rosen et al., 1979, 1982; Byrne, 1980; Walters et al., 1983; Dubuc and Castellucci, 1991), the RM neurons had irregularly shaped and overlapping receptive fields. The receptive fields of the RM neurons were confined chiefly to the toothed chitinous radula surface of the odontophore, although the fields often extended to the tissue just adjacent to the radula. The highest density of fields was found on the posterodorsal portion of the radula, the surface that is contacted when the radula grasps food. Receptive fields did not appear to correlate somatotopically with neuronal position in the ganglion (cf. Spray et al., 1980).

The receptive fields of multiple RM neurons that were examined in individual preparations exhibited considerable variation of size and shape. Figure 8 illustrates one such experiment in which six RM neurons were examined in the right buccal hemiganglion of one animal. The largest RM cells tended to have the largest receptive fields and the lowest sensory thresholds (Fig. $8 A, B$ ). These cells typically responded ( $>50 \%$ of tests) to a $0.1 \mathrm{gm}$ von Frey hair applied to a portion of the biting surface of the radula. The receptive fields of large RM cells covered portions of the left and right radula halves (i.e., they were bilateral). Moderately sized RM neurons also had bilateral receptive fields (Fig. $8 C, D$ ). The fields of these cells were smaller in area than those of the largest cells and the sensory thresholds were usually $\geq 0.5 \mathrm{gm}$. The smallest $\mathrm{RM}$ neurons that could be impaled most often had a single ipsi- or contralateral receptive field (Fig. $8 E, F$ ). Their thresholds were rarely less than $1.0 \mathrm{gm}$.

\section{Electrical coupling among $R M$ cells}

The RM neurons form a network of electrically coupled cells. Coupling coefficients ranging from 0.006 to 0.22 were measured (24 pairs tested). Recording from multiple cells within a hemiganglion provided evidence for both divergent and convergent electrical connections (Fig. 9). Depolarizing suprathreshold pulses injected into each cell resulted in a depolarizing shift of the membrane potential of each of the three coupled cells (Fig. 9 $A-D$, left). Additional deflections corresponding 1:1 with the impulses of the injected cell were typically transmitted less effectively than the DC potentials, indicating that a form of lowpass filtering may occur at these junctions. Injection of hyperpolarizing current pulses into each RM cell resulted in comparable postsynaptic shifts of the membrane potential of the coupled cells, indicating that the coupling between these cells is non-rectifying (Fig. $9 A-D$, right). Although coupling between neuron pairs tended to be symmetrical (Fig. $9 A-C$ ), this was not always the case. For example, in the experiment shown, the effects that one of the neurons (RM-4) exerted on its followers (Fig. 9D) were substantially weaker than the effects that each of the three followers exerted on it (Fig. $9 A-C$, bottom traces).

Electrical coupling of RM neurons was not confined to the ipsilateral hemiganglion. In fact, the most effective coupling (coupling coefficients from 0.14 to $0.22, n=6$ pairs) was found between pairs of the largest ovoid cells, regardless of whether they were located in the ipsi- or contralateral hemiganglion (not shown).

\section{Spontaneous and evoked burst activity of RM neurons}

In isolated ganglion preparations, or in dissected preparations composed of the buccal and cerebral ganglia and the odonto- 


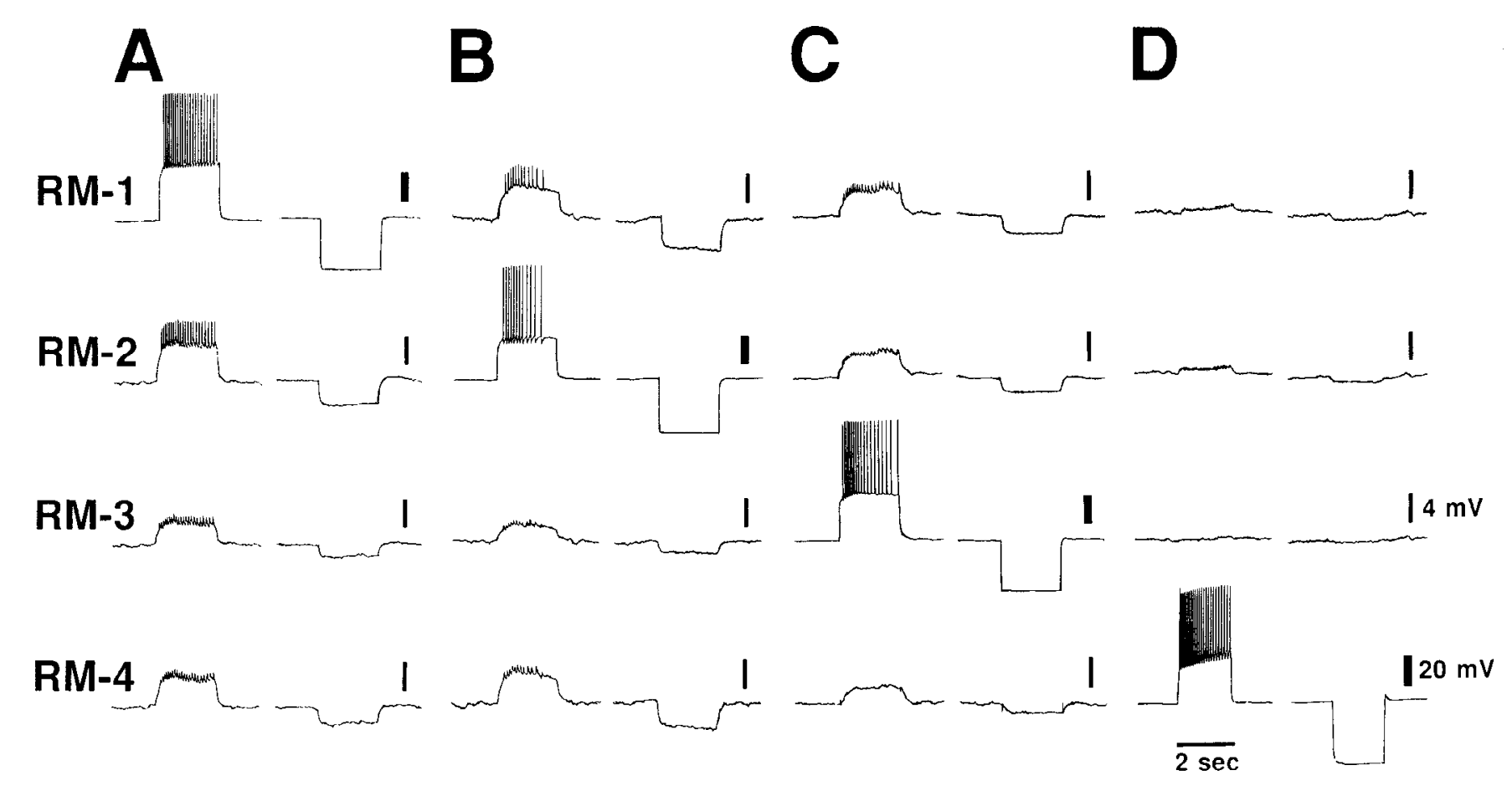

Figure 9. Electrical coupling of RM neurons. Simultaneous recording from four ipsilateral RM neurons $(R M-1-R M-4)$. $A$, Injection of a 2 sec suprathreshold constant current depolarizing pulse into $R M-1$ resulted in depolarizing shifts of varying magnitudes in the membrane potentials of $R M-2, R M-3$, and $R M-4$ (left panels). Note that the gain for the cell into which the current was passed (thick bar calibration: $20 \mathrm{mV}$ ) was higher than for the other cells (thin bar calibration: $4 \mathrm{mV}$ ). Rapid deflections of the membrane potential of the coupled cells correspond to the action potentials in $R M-1$. A, Hyperpolarizing current injected into RM-1 resulted in hyperpolarizing shifts of the membrane potential of each of the coupled cells (right panels). $B-D$, The same protocol as in $A$ was followed with current being injected into $R M-2, R M-3$, and $R M-4$, respectively. Note that whereas the coupling between $R M-1, R M-2$, and $R M-3$ pairs is reciprocal, current injected into $R M-4(D)$ has much less effect on the other cells than vice versa $(A-C$, bottom panels $)$.

phore, RM neurons were generally silent. However, when the buccal ganglion exhibited spontaneous bursts of activity, depolarization and firing of the RM cells occurred in phase with the coordinated burst activity recorded in numerous other buccal cells, including the multifunction neuron B4 (Fig. 10A, top trace; see Susswein and Byrne, 1988 for a description of bursting pattern types). During quiet periods, a brief tactile stimulus applied to the radula could elicit, in addition to short latency sensory responses in RM neurons, a longer latency polysynaptic response associated with an evoked coordinated burst pattern (Fig. 10B). Throughout the coordinated burst, RM cells were tonically depolarized $(5-10 \mathrm{mV})$ to a subthreshold level. During the later phase of B4 firing, RM cells often produced a series of patterned impulses. These action potentials appeared to result from rhythmic suprathreshold synaptic inputs to RM cells.

Bouts of rhythmic burst activity in RM neurons cannot be explained by their peripheral processes being stimulated during movements of the buccal mass, since RM bursts still could be elicited from deafferented buccal ganglia. Continuous rhythmic bursting in RM neurons could be elicited in deafferented ganglia by brief electrical stimulation of buccal nerves (e.g., the radula nerve; see Susswein and Byrne, 1988; Plummer and Kirk, 1990). These bursts, as monitored via the identified neuron B4 (Fig. $11 \mathrm{~A}$, top record), generally correspond to the "pattern 1 " class of Susswein and Byrne (1988). Periodic depolarizations were found to occur in RM cells (Fig. 11A, middle record) in phase with B4 firing. As observed with the spontaneous ganglionic bursting, firing of the RM neurons occurred during the late phase of B4 bursts, and appeared to be produced by patterned synaptic activity (Fig. $11 B$, middle record). The synchronous occurrence of this synaptic activity in multiple RM cells resulted in intense barrages of radula nerve activity (Fig. $11 B$, bottom record). The spontaneous and evoked bursting patterns of the RM cells indicate that these neurons are influenced by the central pattern generator networks that underlie buccal motor programs.

\section{Biochemical characterization of the RM cells}

In order to identify the SCP-immunoreactive peptides present in the RM cells, 43 neurons in this cluster (14 preparations) were physiologically identified, marked by iontophoretic ejection of fast green dye, and incubated in a medium containing radiolabeled methionine, an amino acid present in both $\mathrm{SCP}_{\mathrm{A}}$ and $\mathrm{SCP}_{\mathrm{B}}$. Individual neurons were dissected and pooled, and synthesized radiolabeled peptides were extracted in the presence of sufficient amounts of synthetic $\mathrm{SCP}_{\mathrm{A}}$ and $\mathrm{SCP}_{\mathrm{B}}$ to be detected by absorbance measurements. Samples were then subjected to two stages of RP-HPLC and chromatographic properties of the peptides synthesized by the RM cells were compared to those of the synthetic SCPs (Fig. 12). Different hydrophobic ion pairing reagents were included in the two RP-HPLC passes to decrease the likelihood of coelution of synthetic material and peptides that are not structurally identical to the SCPs (Bennett et al., 1980). Chromatographic properties of the peptides synthesized by the RM cells were determined by counting RP-HPLC fractions. Chromatographic properties of synthetic $\mathrm{SCP}_{\mathrm{A}}$ and $\mathrm{SCP}_{\mathrm{B}}$ were determined by monitoring the absorbance of eluting material at a sensitivity that would detect only the synthetic material added to the cell extract (Fig. 12, arrows). These ex- 


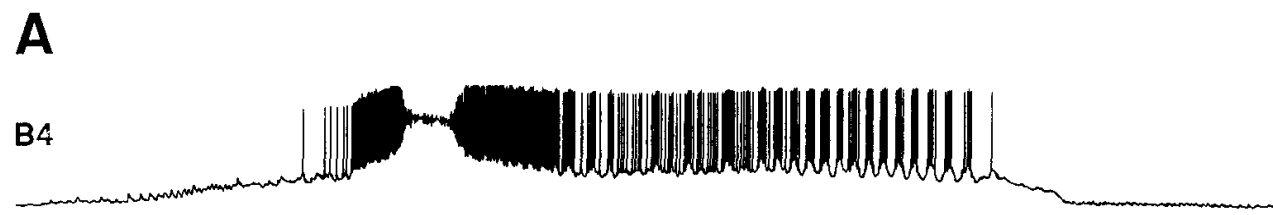

RM-1
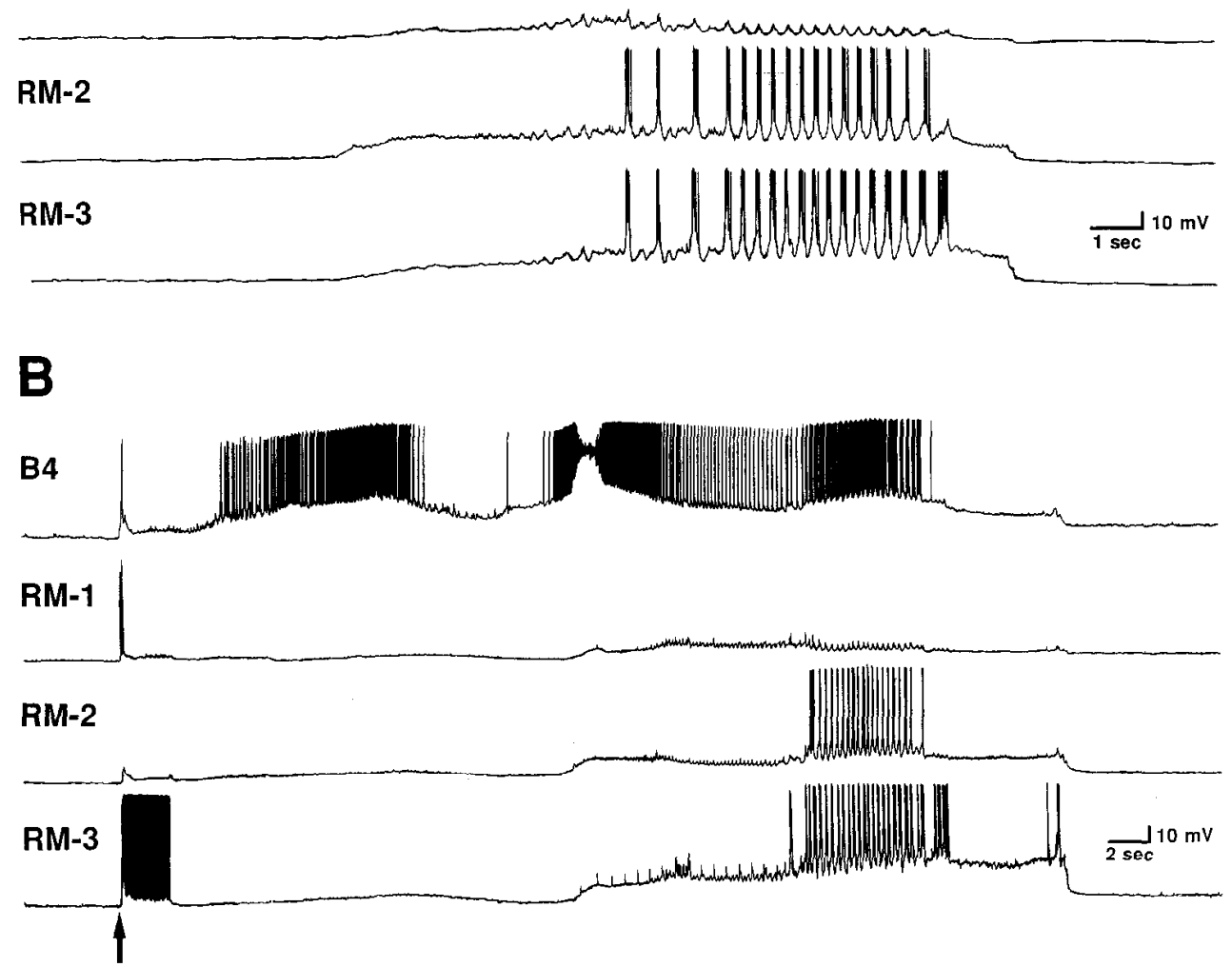

Figure 10. Spontaneous and evoked activity of RM neurons in the odontophore-buccal ganglion preparation. $A$, Simultaneous recording from four ipsilateral neurons in an odontophore-buccal ganglion preparation (see Materials and Methods) that exhibited spontaneous bursting activity. Recording from $B 4$ is used as a reference for determining the phase of activity in the RM neurons $(R M-1, R M-2, R M-3)$. Depolarization of each of the RM neurons occurred in phase with the $B 4$ burst, and two of the RM cells $(R M-2$ and $R M-3)$ produced impulses in a series of brief bursts during the later phase of the $B 4$ firing. Note that all of the cells monitored (including B4) exhibited simultaneous rhythmic membrane potential depolarizations during this late phase of the burst, suggesting that they may receive synaptic input from a common source. $B$, Simultaneous recording from $B 4$ and three ipsilateral RM neurons $(R M-1, R M-2, R M-3)$ in another preparation. This preparation was not bursting spontaneously but a coordinated burst pattern could be evoked by application of a brief tactile stimulus to the surface of the radula (arrow). The three RM neurons were depolarized during the later phase of the $\mathrm{B} 4$ burst and two of the cells $(R M-2$ and $R M-3)$ produced a series of patterned impulses prior to the termination of the $B 4$ burst.

periments indicated that the radula mechanoafferent cells synthesize peptides with chromatographic properties identical to those of the SCPs.

The recent identification of sensorin-A, a neuropeptide localized specifically to mechanosensory neurons of Aplysia (Brunet et al., 1991), prompted us to test whether the RM neurons contain this peptide. Neurons were identified physiologically and functionally, filled with Lucifer yellow dye (Fig. 13 $A$, arrows), fixed, and processed with an antibody raised against a region of the sensorin-A precursor that includes the peptide (Fig. $13 B$ ). Immunoreactive material was not detected in the Lucifer yellow-filled radula mechanoafferent cells or in the neurons in their immediate vicinity. Immunoreactivity was noted, however, in the nearby cluster of s cells (Fig. 13B, upper right) (Fiore and Meunier, 1979; see also Brunet et al., 1991).

\section{Discussion}

The radula mechanoafferent neurons of the rostral cluster This study constitutes an initial characterization of the rostral cluster of SCP-immunoreactive neurons in the buccal ganglion of Aplysia. We are able to conclude that (1) neurons of the rostral group project via the radula nerve to a tissue, designated the subradula tissue, that underlies the chitinous radula; (2) these neurons act as radula mechanoafferents (RMs); that is, they transduce tactile stimuli applied to discrete regions of the radula in a highly sensitive manner; (3) the RM neurons comprise an electrically coupled network; (4) they exhibit burst activity in phase with centrally-generated buccal rhythms; and (5) the RM ncurons synthesizc authentic $\mathrm{SCP}_{\mathrm{A}}$ and $\mathrm{SCP}_{\mathrm{B}}$.

Several limitations regarding the inclusivity and exclusivity 

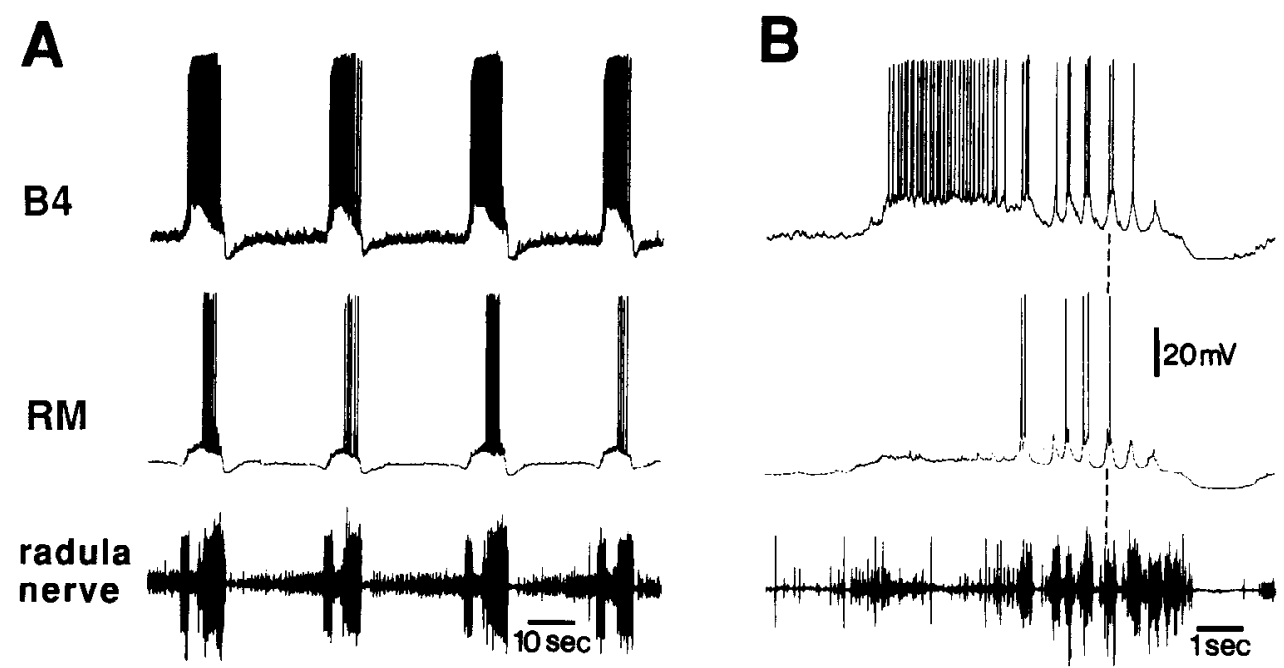

Figure 11. Rhythmic RM neuron activity in the isolated buccal ganglion preparation. Bursting in this ganglion followed a period of electrical stimulation of the radula nerve via a suction electrode ( $2 \mathrm{~Hz}, 20 \mathrm{sec}$; not shown; see Susswein and Byrne, 1988). Activity was monitored using an intracellular recording of interneuron B4 ( $B 4$, top records, $A$ and $B$ ) and an extracellular radula nerve recording (bottom records, $A$ and $B$ ). $A$, Rhythmic bursting in an $R M$ neuron (middle trace) occurs in phase with $B 4$ activity. The RM neuron is depolarized 5-10 mV throughout the period of B4 firing and trains of four to eight impulses occur prior to termination of the B4 burst. An intense barrage of radula nerve activity coincides with the RM cell firing. $B$, Expanded record of a single burst from the same experiment as in $A$. The $R M$ neuron impulses are patterned as a result of large (10-20 mV) depolarizing potentials that appear to occur synchronously in $B 4$ and the $R M$ cell (upper dashed line). Radula nerve activity consists of a series of rapid bursts, probably originating from the coincident synaptic depolarization of a population of RM cells (lower dashed line).

of this characterization must be specificd. The small number of cells sampled in this study relative to the number of neurons in the rostral cluster, coupled with a bias toward sampling larger cells, makes it impossible to conclude that all of the above features apply to all of the neurons in this group. The rostral cluster neurons, in fact, exhibit considerable diversity of size and form, and some cells have been identified as unique individuals (Rosen et al., 1992). Furthermore, there appear to be neurons in the region of the rostral cluster that act as radula mechanoafferents but that do not exhibit $\mathrm{SCP}_{\mathrm{B}}$-like immunoreactivity (Table 2 ).

Mechanosensory cells innervating a number of somatic regions of Aplysia have been described (Byrne et al., 1974; Byrne, 1980; Rosen et al., 1979, 1982; Walters et al., 1983; Dubuc and Castellucci, 1991). These neurons typically have small pigmented cell bodies and occur in clusters within the central ganglia, with members of a particular cluster innervating irregular and overlapping fields in a certain part of the body. There are, however, also examples of large individual mechanosensory neurons in

Figure 12. Comparison of the chromatographic properties of ${ }^{35} \mathrm{~S}$ methionine-labeled peptides synthesized by 43 radula mechanoafferent neurons and $\mathrm{SCP}_{\mathrm{A}}$ and $\mathrm{SCP}_{\mathrm{B}}$. Radiolabeled peptides synthesized by radula mechanoafferent cells were subjected to two stages of sequential RP-HPLC in the presence of nanomolar quantities of synthetic $\mathrm{SCP}_{\mathrm{A}}$ and $\mathrm{SCP}_{\mathrm{B}}, A$, Stage 1 of chromatography was performed in the presence of $0.01 \mathrm{M}$ TFA. Flution times of synthetic peptides are indicated by arrows. The elution times of radiolabeled peptides were determined by counting $10 \%$ of each RP-HPLC fraction (counts/whole fraction are plotted). $B$, Stage 2 of chromatography was performed in the presence of 0.01 м HFBA. Rechromatography of the $S_{C P}$ peak is shown in $B 1$, rechromatography of the $\mathrm{SCP}_{\mathrm{B}}$ peak in $B 2$. Note that the radula mechanoafferent neurons synthesize radiolabeled peptides that precisely coelute with synthetic $\mathrm{SCP}_{\mathrm{A}}$ and $\mathrm{SCP}_{\mathrm{B}}$.
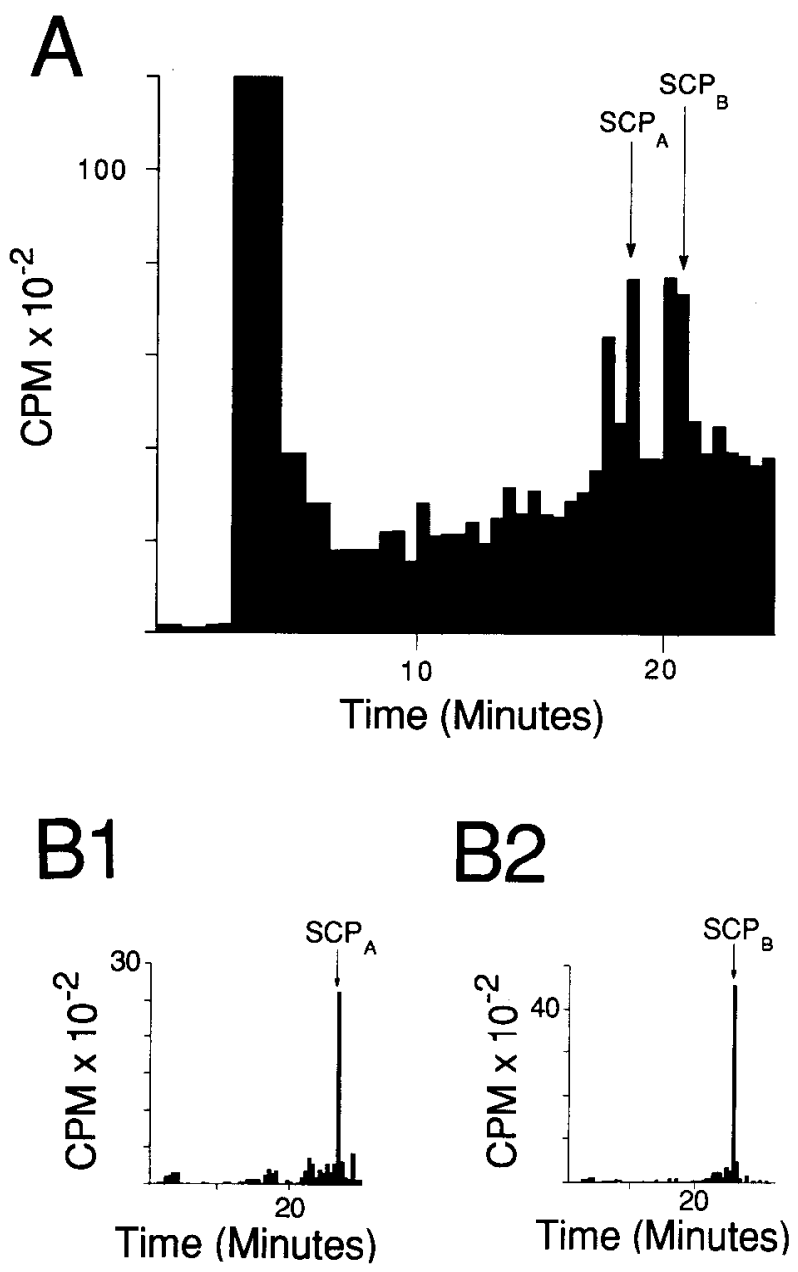

Time (Minutes) 

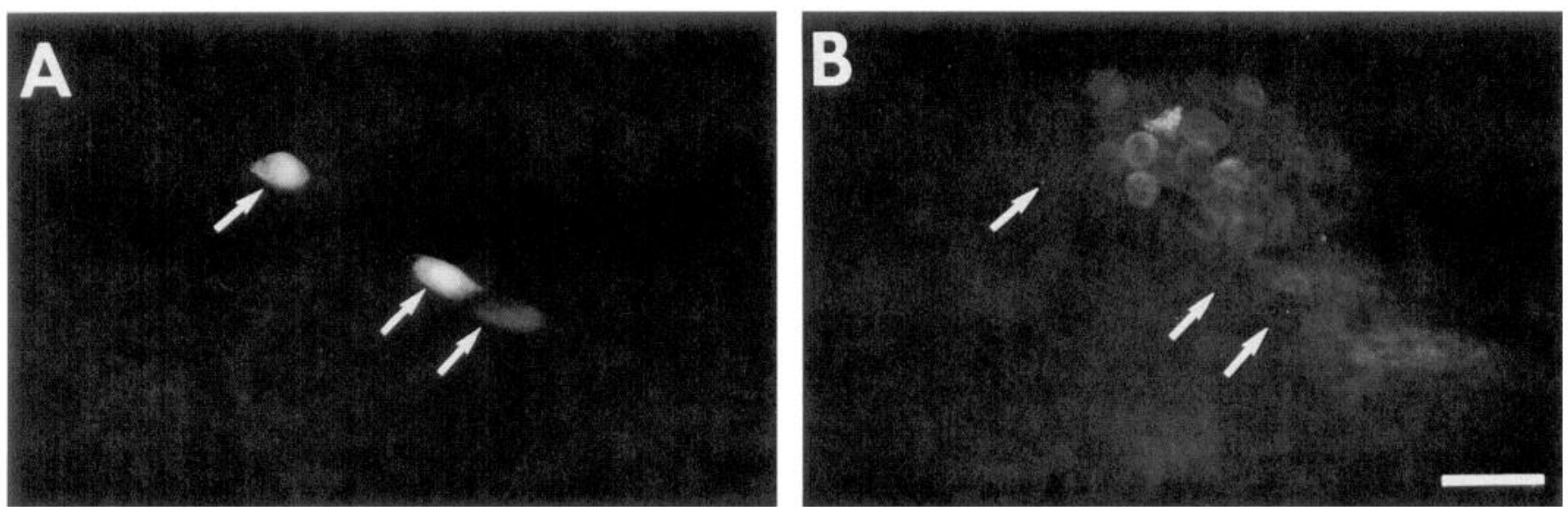

Figure 13. The radula mechanoafferent neurons do not exhibit sensorin-like immunoreactivity. $A$, Three radula mechanoafferent neurons were physiologically identified and filled with Lucifer yellow dye. $B$, Same hemiganglion shown in $A$ following processing for sensorin-like immunoreactivity (rhodamine-coupled second antibody). Arrows indicate positions of three RM cells shown in $A$. Immunoreactive material was not detected in these three cells but was present in the nearby cluster of $\mathrm{s}$ mechanosensory cells (located above and to the right of the arrows; see Brunet et al., 1991). Scale bar, $100 \mu \mathrm{m}$.

Aplysia (Cobbs and Pinsker, 1978; Jahan-Parwar et al., 1983; Weiss et al., 1986b,c). The RM cell groups, which consist of moderately sized nonpigmented cells, appear to represent a distinct class of mechanosensory cells that differ in a number of respects from previously described sensory neuron clusters: (1) the responses of RM neurons exhibit very rapid sensory adaptation, (2) they are electrically coupled to one another, (3) they synthesize the SCPs, and (4) they do not exhibit sensorinA-like immunoreactivity. It appears that the neurons that can be classified as mechanosensory in Aplysia exhibit considerable heterogeneity of size, form, electrophysiological properties, synaptic connectivities, and transmitter substances. Diverse classes of mechanosensory neurons have for some time been known to occur in mammals (see Burgess and Perl, 1973), annelids (Nicholls and Baylor, 1968), and crustaceans (Bush and Laverack, 1982).

\section{The small cardioactive peptides in sensory neurons}

The SCPs are present in certain motor neurons (Cropper et al., 1987a; Sossin et al., 1987; Lloyd et al., 1988; Church and Lloyd, 1991; Church et al., 1991) and interneurons (Alevizos et al., 1989) of the Aplysia nervous system. Their synthesis in a particular class of mechanosensory neurons, the RM cells of the buccal ganglion, further supports the role of these peptides in multiple neuron types and diverse circuits in Aplysia (see Lloyd et al., 1985; Lloyd, 1986). In motor systems, the SCPs are produced in identified neurons (Lloyd et al., 1985; Cropper et al., 1987a; Kreiner et al., 1987; Church and Lloyd, 1991; Church et al., 1991), where they are localized to the secretory pathway (Kreiner et al., 1986; Reed et al., 1988), transported to the periphery (Lloyd, 1988), and released in response to stimulation (Lloyd et al., 1986; Whim and Lloyd, 1989; Cropper et al., 1990; Vilim et al., 1991). The actions of these peptides on the tissues innervated are consistent with a transmitter or cotransmitter role for the SCPs in these systems (Lloyd et al., 1984, 1988; Cropper et al., 1987a).

The possibility that the SCPs serve a signaling function in central circuits is suggested by their actions on neurons (Abrams et al., 1984; Sossin et al., 1987; Alevizos et al., 1989; Plummer and Kirk, 1990). We have observed responses in follower neu- rons that indicate that the RM cells may utilize the SCPs in central signaling (Rosen et al., 1992). It is not presently known whether the SCPs are colocalized in the rostral cluster cells with a classical primary transmitter (see Cropper et al., 1987a; Lloyd et al., 1988) or with additional neuropeptides. Sensorin-A, a candidate cotransmitter that has been shown to occur in several groups of Aplysia mechanosensory neurons (Brunet et al., 1991) was not detected immunohistologically in the RM cells. FMRFamide-like immunoreactivity has been observed in the $s$ cell cluster of the buccal ganglion (Lloyd et al., 1987a) and is present in some cells in the region of the rostral cluster (F. S. Vilim, M. W. Miller, S. C. Rosen, and K. R. Weiss, unpublished observations), but the colocalization of the SCPs and FMRFamide-related peptides in these cells has not been examined.

The presence of SCP peptides in the subradula tissue raises the possibility that the peptides may be released from RM sensory terminals in that tissue. A number of peripheral effects of peptides originating from sensory neurons have been described in vertebrates (see Franco-Cereceda et al., 1987; Holzer, 1988). The subradula tissue appears to contain muscle fibers and to exhibit contractility (our observations and F. S. Vilim, personal communication), and it is possible that release of the SCPs could regulate contractions in this tissue. Furthermore, if SCP autoreceptors are present on the RM cells themselves, they could act in an automodulatory fashion to alter their own responsiveness to successive stimuli (see Pasztor and Bush, 1987; Siwicki et al., 1987). Finally, in view of the modulatory effects of the SCPs on synaptic properties of other classes of mechanosensory neurons (Abrams et al., 1984; Ocorr and Byrne, 1985; Rosen et al., 1989; Pieroni and Byrne, 1992), it would be of interest to test for possible presynaptic automodulatory effects of these peptides at RM cell central synapses.

\section{$R M$ neurons and buccal ganglion rhythm generation}

Sensory systems may be strongly influenced by pattern-generating networks, and are in turn able to regulate multiple aspects of the CPGs, for example, frequency, phase transitions, and switching (Pearson and Ramirez, 1990; Grillner et al., 1991), in part by the release of neuromodulator substances that produce long-lasting modifications of the functional properties of motor 
networks (Hooper and Moulins, 1989; Katz and Harris-Warrick, 1989; see Pearson, 1993). Mechanosensory neurons have been shown to modulate the feeding systems of several mollusks (Kater and Rowell, 1973; Siegler, 1977; Audesirk, 1979; Elliott and Benjamin, 1989), including Aplysia (Jahan-Parwar et al., 1983; Chiel et al., 1986; Weiss et al., 1986a). A possible role for the RM cells in some aspect of the generation or modulation of buccal fceding or rejection programs is suggested by the rhythmic responses produced in buccal neurons upon application of the SCPs (Sossin et al., 1987; Plummer and Kirk, 1990; see also Murphy et al., 1985; Prior and Watson, 1988; Willows et al., 1988). Synaptic connections between RM neurons and certain interneurons and motor neurons are consistent with such a role (Rosen et al., 1992). Overall, the properties of the RM neurons suggest that they may function to detect the capture of ingested material and may thereby either reinforce the feeding motor program, signal the switch from biting to swallowing, or perhaps signal rejection responses when inedible objects are ingested.

\section{Central activation of $R M$ neurons}

A remarkable feature of the RM neurons is that although they are sensory neurons that are activated by peripheral mechanostimulation, they also can be excited by activity of central origin (see also Cobbs and Pinsker, 1978; Beltz and Gelperin, 1980a,b; Jahan-Parwar et al., 1983; Dubuc et al., 1988; Cohen, 1992). The excitatory input to the RM cells in isolated ganglia is rhythmic and hence presumably is driven by a central pattern generator network. The central input to the RM neurons appears to occur in phase with the firing of the B4/B5 neurons, a phase during which the radula may normally receive mechanosensory input during radula closing on food (Rosen et al., unpublished observations). There are at least three possible functions for the central activation of the RM neurons. First, the spike activity could serve a sensory-like function, substituting a type of illusory afferent input even in the absence of appropriate sensory input at one phase of the centrally generated program. Second, the depolarizing input to the RM cells could serve to reinforce phaseappropriate sensory input, such that mechanostimulation of the radula would evoke more effective firing of the RM neurons, or more effective synaptic output of the cells, when the stimulation occurred at an appropriate phase (see Weiss' et al., 1986c, for references to numerous examples of phase-appropriate modulation of primary afferent input by means of inhibitory rather than excitatory input). Furthermore, bursts of impulses recorded from the radula nerve in the isolated ganglion (Fig. 10) indicate that the centrally generated spikes of the RM neurons conduct down the nerve toward the periphery. Cobbs and Pinsker (1978) have suggested that the collision of impulses that would occur upon simultaneous central and peripheral activation in bidirectionally conducting mechanosensory neurons could represent a primitive form of centrifugal control of sensory input. Third, the centrally evoked spiking of the RM cells could serve some as yet unspecified efferent function. Movements of the buccal mass have never been observed in response to firing of RM neurons, but it is possible that these cells contribute to the SCP modulation of neuromuscular transmission that has been observed in radula nerve-muscle preparations (Richmond et al., 1986; see also Lloyd et al., 1984; Cropper et al., 1987a). Further analysis of the functional role of the RM neurons would be greatly facilitated by the identification of individual RM neurons with specified response properties, electrophysiological and structural features, and synaptic connectivities (Rosen et al., 1992).

\section{References}

Abrams TW, Castellucci VF, Camardo JS, Kandel ER, Lloyd PE (1984) Two endogenous neuropeptides modulate the gill and siphon withdrawal reflex in Aplysia by presynaptic facilitation involving cAMPdependent closure of a serotonin-sensitive potassium channel. Proc Natl Acad Sci USA 81:7956-7960.

Alevizos A, Weiss KR, Koester J (1989) SCP-containing R20 neurons modulate respiratory pumping in Aplysia. J Neurosci 9:3058-3071.

Audesirk TE (1979) Oral mechanoreceptors in Tritonia diomedia. I. Electrophysiological properties and location of receptive fields. J Comp Physiol 130:71-78.

Beltz B, Gelperin A (1980a) Mechanosensory input modulates activity of an autoactive, bursting neuron in Limax maximus. J Neurophysiol 44:665-674.

Beltz B, Gelperin A (1980b) Mechanisms of peripheral modulation of salivary burster in Limax maximus: a presumptive sensorimotor neuron. J Neurophysiol 44:675-686.

Benjamin PR, Rose RM (1979) Central generation of bursting in the feeding system of the snail Lymnaea stagnalis. J Exp Biol 80:93-118.

Bennett HPJ, Browne CA, Solomon S (1980) The use of perfluorinated carboxylic acids in the reverse-phase of HPLC. J Liquid Chromatogr 3:1353-1365.

Berry MS (1972) Electrotonic coupling between identified large cells in the buccal ganglia of Planorbis corneus. J Exp Biol 57:173-185.

Brunet J-F, Shapiro E, Foster SA, Kandel ER, Iino Y (1991) Identification of a peptide specific for Aplysia sensory neurons by PCRbased differential screening. Science 252:856-859.

Burgess PR, Perl ER (1973) Cutaneous mechanoreceptors and nociceptors. In: Handbook of sensory physiology: somatosensory system (Iggo A, ed), pp 29-78. Heidelberg: Springer.

Bush BMH, Laverack MS (1982) Mechanoreception. In: The biology of crustacea, Vol 3, Neurobiology: structure and function (Atwood HL, Sandeman DG, eds), pp 399-468. New York: Academic.

Byrne JH (1980) Neural circuit for inking behavior in Aplysia californica. J Neurophysiol 43:896-911.

Byrne J, Castellucci V, Kandel ER (1974) Receptive fields and response properties of mechanoreceptor neurons innervating siphon skin and mantle shelf in Aplysia. J Neurophysiol 37:1041-1064.

Cash D, Carew TJ (1989) A quantitative analysis of the development of the central nervous system in juvenile Aplysia californica. J Neurobiol 20:25-47.

Chiel HJ, Weiss KR, Kupfermann I (1986) An identified histaminergic neuron modulates feeding motor circuitry in Aplysia. J Neurosci 6:2427-2450.

Church PJ, Lloyd PE (1991) Expression of diverse neuropeptide cotransmitters by identified motor neurons in Aplysia. J Neurosci 11: 618-625.

Church PJ, Cohen KP, Scott ML, Kirk MD (1991) Peptidergic motoneurons in the buccal ganglia of Aplysia californica: immunocytochemical, morphological, and physiological charactcrizations. J Comp Physiol [A] 168:323-336.

Cobbs JS, Pinsker HM (1978) In vivo responses of paired giant mechanoreceptor neurons in Aplysia abdominal ganglion. J Neurobiol 9:121141

Cohen AH (1992) The role of heterarchical control in the evolution of central pattern generators. Brain Behav Evol 40:112-124.

Cohen JL, Weiss KR, Kupfermann I (1978) Motor control of buccal muscles in Aplysia. J Neurophysiol 41:157-180.

Cropper EC, Lloyd PE, Reed W, Tenenbaum R, Kupfermann I, Weiss KR (1987a) Multiple neuropeptides in cholinergic motor neurons of Aplysia: evidence for modulation intrinsic to the motor circuit. Proc Natl Acad Sci USA 84:3486-3490.

Cropper EC, Tenenbaum R, Kolks MAG, Kupfermann I, Wciss KR (1987b) Myomodulin: a bioactive neuropeptide present in an identified cholinergic buccal motor neuron of Aplysia. Proc Natl Acad Sci USA 84:5483-5486.

Cropper EC, Miller MW, Tenenbaum R, Kolks MAG, Kupfermann I, Weiss KR (1988) Structure and action of buccalin: a modulatory neuropeptide localized to an identified small cardioactive peptidecontaining cholinergic motor neuron of Aplysia californica. Proc Natl Acad Sci USA 85:6177-6181.

Cropper EC, Price D, Tenenbaum R, Kupfermann I, Weiss KR (1990) Release of peptide cotransmitters from a cholinergic motor neuron under physiological conditions. Proc Natl Acad Sci USA 87:933-937.

Davis WJ, Mpitsos GJ, Siegler MVS, Pinneo JM, Davis KB (1974) 
Neuronal substrates of behavioral hierarchies and associative learning in Pleurobranchaea. Am Zool 14:1037-1050.

Davis WJ, Mpitsos GJ, Pinneo JM, Ram JL (1977) Modification of the behavioral hierarchy of Pleurobranchaea. I. Satiation and feeding motivation. J Comp Physiol 117:99-125.

Dubuc B, Castellucci VF (1991) Receptive fields and properties of a new cluster of mechanoreceptor neurons innervating the mantle region and the branchial cavity of the marine mollusk Aplysia californica. J Exp Biol 156:315-334.

Dubuc R, Cabelguen J-M, Rossignol S (1988) Rhythmic fluctuations of dorsal root potentials and antidromic discharges of primary afferents during fictive locomotion in the cat. J Neurophysiol 60:20142036.

Elliott CJH, Benjamin PR (1989) Esophageal mechanoreceptors in the feeding system of the pond snail, Lymnaea stagnalis. J Neurophysiol 61:727-736

Evans BD, Calabrese RL (1989) Small cardioactive peptide-like immunoreactivity and its colocalization with FMRFamide-like immunoreactivity in the central nervous system of the leech Hirudo medicinalis. Cell Tissue Res 257:187-199.

Fiore L, Meunier J-M (1979) Synaptic connections and functional organization in Aplysia buccal ganglia. J Neurobiol 10:13-29.

Franco-Cereceda A, Henke H, Lundberg JM, Petermann JB, Hökfelt T, Fischer JA (1987) Calcitonin gene-related peptide (CGRP) in capsaicin-sensitive substance P-immunoreactive sensory neurons in animals and man: distribution and release by capsaicin. Peptides $8: 399-410$.

Fredman SM, Jahan-Parwar B (1980) Processing of chemosensory and mechanosensory information in identifiable Aplysia neurons. Comp Biochem Physiol [A] 66:25-34.

Gardner D (1971) Bilateral symmetry and interneuronal organization in the buccal ganglia of Aplysia. Science 173:550-553.

Gardner D, Kandel ER (1977) Physiological and kinetic properties of cholinergic receptors activated by multiaction interneurons in buccal ganglia of Aplysia. J Neurophysiol 40:333-348.

Geduldig D, Junge D (1968) Sodium and calcium components of action potentials in the Aplysia giant neurone. J Physiol (Lond) 199: $347-365$.

Gelperin A, Hopfield JJ, Tank DW (1985) The logic of Limax learning. In: Model neural networks and behavior (Selverston AI, ed), pp 237261. New York: Plenum.

Grillner S, Wallen P, Brodin L, Lansner A (1991) Neuronal network generating locomotor behavior in lamprey. Annu Rev Neurosci 14: 169-200.

Holzer P (1988) Local effector functions of capsaicin-sensitive sensory nerve endings: involvement of tachykinins, calcitonin gene-related peptide and other neuropeptides. Neuroscience 24:739-768.

Homberg U, Hildebrand JG (1989) Serotonin immunoreactivity in the optic lobes of the sphinx moth Manduca sexta and colocalizaton with FMRFamide and $\mathrm{SCP}_{\mathrm{B}}$ immunoreactivity. J Comp Neurol 288: 243-253.

Hooper SL, Moulins M (1989) Switching of a neuron from one network to another by sensory-induced changes in membrane properties. Science 244:1587-1589.

Horn R (1978) Propagating calcium spikes in an axon of Aplysia. J Physiol (Lond) 281:513-534.

Jahan-Parwar B (1972) Behavioral and electrophysiological studies on chemoreception in Aplysia. Am Zool 12:525-537.

Jahan-Parwar B, Wilson AH Jr, Fredman SM (1983) Role of proprioceptive reflexes in control of feeding muscles of Aplysia. J Neurophysiol 49:1469-1480.

Kater SB (1974) Feeding in Helisoma trivolvis: the morphological and physiological bases of a fixed action pattern. Am Zool 14:1017-1036.

Kater SB, Rowell CHF (1973) Integration of sensory and centrally programmed components in generation of cyclical feeding activity of Helisoma trivolvis. J Neurophysiol 36:142-155.

Katz PS, Harris-Warrick RM (1989) Serotonergic/cholinergic muscle receptor cells in the crab stomatogastric nervous system. II. Rapid nicotinic and prolonged modulatory effects on neurons in the stomatogastric ganglion. J Neurophysiol 62:571-581.

Kirk MD, Scheller RH (1986) Egg-laying hormone of Aplysia induces a voltage-dependent slow inward current carried by $\mathrm{Na}^{+}$in an identified motoneuron. Proc Natl Acad Sci USA 83:3017-3021.

Kovac MP, Matera EM, Volk PJ, Davis WJ (1986) Food avoidance learning is accompanied by synaptic attenuation in identified interneurons controlling feeding behavior in Pleurobranchaea. J Neurophysiol 56:891-905.

Kreiner T, Sossin W, Scheller RH (1986) Localization of Aplysia neurosecretory peptides to multiple populations of dense core vesicles. J Cell Biol 102:769-782.

Kreiner T, Kirk MD, Scheller RH (1987) Cellular and synaptic morphology of a feeding motor circuit in Aplysia californica. J Comp Neurol 264:311-325

Kupfermann I (1974a) Feeding behavior in Aplysia: a simple system for the study of motivation. Behav Biol 10:1-26.

Kupfermann I (1974b) Dissociation of the appetitive and consummatory phases of feeding behavior in Aplvsia: a lesion study. Behav Biol 10:89-97.

Kupfermann I, Rosen S, Teyke T, Cropper EC, Miller M, Vilim F, Weiss KR (1989) Neurobiology of behavioral states in Aplysia: nonassociative forms of plasticity of feeding responses. In: Dynamics and plasticity in neuronal systems (Elsner N, Singer W, eds), pp 47-59. New York: Thieme.

Lent CM, Dickinson MH, Marshall CG (1989) Serotonin and leech feeding behavior: obligatory neuromodulation. Am Zool 29:12411254.

Libersat F, Levy A, Camhi JM (1989) Multiple feedback loops in the flying cockroach: excitation of the dorsal and inhibition of the ventral giant interneurons. J Comp Physiol [A] 165:651-668.

Lloyd PE (1982) Cardioactive neuropeptides in gastropods. Fed Proc 41:2948-2952.

Lloyd PE (1986) The small cardioactive peptides: a class of modulatory neuropeptides in Aplysia. Trends Neurosci 9:428-432.

Lloyd PE (1988) Fast axonal transport of modulatory neuropeptides from central ganglia to components of the feeding system in Aplysia. J Neurosci 8:3507-3514.

Lloyd PE, Kupfermann I, Weiss KR (1984) Evidence for parallel actions of a molluscan neuropeptide and serotonin in mediating arousal in Aplysia. Proc Natl Acad Sci USA 81:2934-2937.

Lloyd PE, Mahon AC, Kupfermann I, Cohen JL, Scheller RH, Weiss KR (1985) Biochemical and immunocytological localization of molluscan small cardioactive peptides in the nervous system of Aplysia californica. J Neurosci 5:1851-1861.

Lloyd PE, Schacher S, Kupfermann I, Weiss KR (1986) Release of neuropeptides during intracellular stimulation of single identified Aplysia neurons in culture. Proc Natl Acad Sci USA 83:9794-9798.

Lloyd PE, Frankfurt M, Stevens P, Kupfermann I, Weiss KR (1987a) Biochemical and immunocytological localization of the neuropeptides FMRFamide, $\mathrm{SCP}_{\mathrm{A}}, \mathrm{SCP}_{\mathrm{B}}$, to neurons involved in the regulation of feeding in Aplysia. J Neurosci 7:1123-1132.

Lloyd PE, Kupfermann I, Weiss KR (1987b) Sequence of small cardioactive peptide A: a second member of a class of neuropeptides in Aplysia. Peptides 8:179-184.

Lloyd PE, Kupfermann 1, Weiss KR (1988) Central peptidergic neurons regulate gut motility in Aplysia. J Neurophysiol 59:1613-1626.

Longley RD, Longley AJ (1986) Serotonin immunoreactivity of neurons in the gastropod Aplysia californica. J Neurobiol 17:339-358.

Marder E (1988) Modulating a neuronal network. Nature 335:296297.

Miller MW, Kupfermann I, Weiss KR (1988) Characterization of SCP $_{b}$ immunoreactive cells in the buccal ganglion of Aplysia. Soc Neurosci Abstr 14:536.

Miller MW, Alevizos A, Cropper EC, Vilim FS, Karagogeos D, Kupfermann I, Weiss KR (1991) Localization of myomodulin-like immunoreactivity in the central nervous system and peripheral tissues of Aplysia californica. J Comp Neurol 314:627-644.

Morris HR, Panico M, Karplus A, Lloyd PE, Riniker B (1982) Elucidation by FAB-MS of the structure of a new cardioactive peptide from Aplysia. Nature 300:643-645.

Murphy AD, Lukowiak K, Stell WK (1985) Peptidergic modulation of patterned motor activity in identified neurons of Helisoma. Proc Natl Acad Sci USA 82:7140-7144.

Nicholls JG, Baylor DA (1968) Specific modalities and receptive fields of sensory neurons in CNS of the leech. J Neurophysiol 31:740-756.

Ocorr KA, Byrne JH (1985) Membrane responses and changes in c $\Lambda$ MP levels in Aplysia sensory neurons produced by serotonin, tryptamine, FMRFamide and small cardioactive peptide ${ }_{\mathrm{B}}\left(\mathrm{SCP}_{\mathrm{B}}\right)$. Neurosci Lett 55:113-118. 
Ono JK (1989) Synaptic connections in the buccal ganglia of Aplysia mediated by an identified neuron containing a CCK/gastrin-like peptide co-localized with acetylcholine. Brain Res 493:212-224.

Pasztor VM, Bush BMH (1987) Peripheral modulation of mechanosensitivity in primary afferent neurons. Nature 326:793-795.

Pearson KG (1993) Common principles of motor control in vertebrates and invertebrates. Annu Rev Neurosci 16:256-297.

Pearson KG, Ramirez JM (1990) Influence of input from the forewing stretch receptors on motoneurones in flying locusts. J Exp Biol 151: 317-340.

Pieroni JP, Byrne JH (1992) Differential effects of serotonin, FMRFamide, and small cardioactive peptide on multiple, distributed processes modulating sensorimotor synaptic transmission in Aplysia. J Neurosci 12:2633-2647.

Plummer MR, Kirk MD (1990) Premotor neurons B51 and B52 in the buccal ganglia of Aplysia californica: synaptic connections, effects on ongoing motor rhythms, and peptide modulation. J Neurophysiol 63:539-558.

Prior DJ, Watson WH III (1988) The molluscan neuropeptide, $\mathrm{SCP}_{\mathrm{B}}$, increases the responsiveness of the feeding motor program of Limax maximus. J Neurobiol 19:87-105.

Rao G, Barnes CA, McNaughton BL (1986) Intracellular fluorescent staining with carboxyfluorescein: a rapid and reliable method for quantifying dye-coupling in mammalian central nervous system. J Neurosci Methods 16:251-263.

Reed W, Weiss KR, Lloyd PE, Kupfermann I, Chen M, Bailey CH (1988) Association of neuroactive peptides with the protcin secretory pathway in identified neurons of Aplysia californica: immunolocalization of $\mathrm{SCP}_{\mathrm{A}}$ and $\mathrm{SCP}_{\mathrm{B}}$ to the contents of dense-core vesicles and the trans face of the Golgi apparatus. J Comp Neurol 272:358-369.

Richmond JE, Bulloch AGM, Lukowiak K (1986) Peptidergic modulation of a neuromuscular junction in Aplysia: bioactivity and immunocytochemistry. Brain Res 370:159-164.

Rosen SC, Weiss KR, Kupfermann I (1979) Response properties and synaptic connections of mechanoafferent neurons in cerebral ganglion of Aplysia. J Neurophysiol 42:954-974.

Rosen SC, Weiss KR, Cohen JL, Kupfermann I (1982) Interganglionic cerebral-buccal mechanoafferents of Aplysia: receptive fields and synaptic connections to different classes of neurons involved in feeding behavior. J Neurophysiol 48:271-288.

Rosen SC, Susswein AJ, Cropper EC, Weiss KR, Kupfermann I (1989) Selective modulation of spike duration by serotonin and the neuropeptides, FMRFamide, $\mathrm{SCP}_{\mathrm{B}}$, buccalin and myomodulin in different classes of mechanoafferent neurons in the cerebral ganglion of Aplysia. J Neurosci 9:390-402.

Rosen SC, Teyke T, Miller MW, Weiss KR, Kupfermann I (1991) Identification and characterization of cerebral-to-buccal interneurons implicated in the control of motor programs associated with feeding in Aplysia. J Neurosci 11:3630-3655.

Rosen SC, Miller MW, Weiss KR, Kupfermann I (1992) SCP-containing radula mechanoafferent neurons in the buccal ganglion of Aplysia: synaptic connectivity of identified cells. Soc Neurosci Abstr 18:1279.

Siegler MVS (1977) Motor neurone coordination and sensory modulation in the feeding system of the mollusc Pleurobranchaea californica. J Exp Biol 71:27-48.

Siwicki KK, Beltz BS, Kravitz EA (1987) Proctolin in identified serotonergic, dopaminergic, and cholinergic neurons in the lobster, Homarus americanus. J Neurosci 7:522-532.

Sossin WS, Kirk MD, Scheller RH (1987) Peptidergic modulation of neuronal circuitry controlling feeding in Aplysia. J Neurosci 7:671681.

Spray DC, Spira ME, Bennett MVL (1980) Peripheral fields and branching patterns of buccal mechanosensory neurons in the opisthobranch mollusc, Navanax inermis. Brain Res 182:253-270.

Steinberg TH, Newman AS, Swanson JA, Silverstein SC (1987) Macrophages possess probenecid-inhibitable organic anion transporters that remove fluorescent dyes from the cytoplasmic matrix. J Cell Biol 105:2695-2702.

Stewart WW (1978) Functional connections between cells as revealed by dye-coupling with a highly fluorescent naphthalimide tracer. Cell 14:741-759.

Susswein AJ, Byrne JH (1988) Identification and characterization of neurons initiating patterned neural activity in the buccal ganglia of Aplysia. J Neurosci 8:2049-2061.

Susswein AJ, Weiss KR, Kupfermann I (1978) The effects of food arousal on the latency of biting in Aplysia. J Comp Physiol [A] 123: 31-41.

Taussig R, Sweet-Cordero A, Scheller RH (1989) Modulation of ionic currents in Aplysia motor neuron B15 by serotonin, neuropeptides, and second messengers. J Neurosci 9:3218-3229.

Trimble DL, Barker DL (1984) Activation by dopamine of patterned motor output from the buccal ganglia of Helisoma trivolvis. J Neurobiol 15:37-48.

Vilim FS, Price DA, Lesser W, Kupfermann I, Weiss KR (1991) Direct measurement of peptide co-transmitter release following intracellular stimulation of a single identificd motorncuron in Aplysia. Soc Neurosci Abstr 17:1305.

Walters ET, Byrne JH, Carew TJ, Kandel ER (1983) Mechanoafferent neurons innervating tail of Aplysia. I. Response properties and synaptic connections. J Neurophysiol 50:1522-1542.

Watson WH III, Willows AOD (1992) Evidence for homologous peptidergic neurons in the buccal ganglia of diverse nudibranch mollusks. J Neurobiol 23:173-186.

Weiss KR, Cohen JL, Kupfermann I (1978) Modulatory control of buccal musculature by a serotonergic neuron (metacerebral cell) in Aplysia. J Neurophysiol 41:181-203.

Weiss KR, Shapiro E, Kupfermann I (1986a) Modulatory synaptic actions of an identified histaminergic neuron on the serotonergic metacerebral cell of Aplysia. J Neurosci 6:2393-2402.

Weiss KR, Chiel IIJ, Koch U, Kupfermann I (1986b) Activity of an identified histaminergic neuron, and its possible role in arousal of feeding behavior in semi-intact Aplysia. J Neurosci 6:2403-2415.

Weiss KR, Chiel HJ, Kupfermann I (1986c) Sensory function and gating of histaminergic neuron C2 in Aplysia. J Neurosci 6:24162426.

Welsford IG, Prior DJ (1991) Modulation of heart activity in the terrestrial slug Limax maximus by the feeding motor program, small cardioactive peptides and stimulation of buccal neuron B1. J Exp Biol 155:1-19.

Whim MD, Lloyd PE (1989) Frequency-dependent release of peptide cotransmitters from identified cholinergic motor neurons in Aplysia. Proc Natl Acad Sci USA 86:9034-9038.

Willows AOD, Lloyd PE, Masinovsky BP (1988) Multiple transmitter neurons in Tritonia. III. Modulation of central pattern generator controlling feeding. J Neurobiol 19:69-86.

Zoran MJ, Haydon PG, Matthews PJ (1989) Aminergic and peptidergic modulation of motor function at an identified neuromuscular junction in Helisoma. J Exp Biol 142:225-243. 